\title{
Trade Retaliation in a Monetary-Trade Model
}

\author{
JOHN WHALLEY \\ JUN YU \\ SHUNMING ZHANG
}
CESIFO WORKING PAPER NO. 2526
CATEgORY 7: TRADE POLICY
JANUARY 2009
An electronic version of the paper may be downloaded
- from the SSRN website:
- from the RePEc website:
- from the CESifo website:
www.SSRN.com
Www.RePEc.org
www.CESifo-group.org/wp




\title{
Trade Retaliation in a Monetary-Trade Model
}

\begin{abstract}
We explore how outcomes of trade policy retaliation (Nash tariff games) are affected when trade simultaneously takes places geographically across countries and through time via financial intermediation. In such models deficits and surpluses in goods trade are endogenously determined, and retaliatory trade policy towards goods can affect these and monetary trade models show different retaliatory trade outcomes from conventional goods only models. We use a general equilibrium goods trade model which also captures trade through time in the form of inside money as used in macro literature on one good overlapping generations models. In this model the deficit or surplus of any country in goods trade is endogenous determined. Optimal trade policy differs from that in a conventional goods only trade model in that countries which run trade deficits in goods will have more strategic power through tariff policy (and surplus countries less) than in models with balanced trade. We calibrate such a model to China's trade with the rest of the world and explore two country tariff games using 2005 data. Results show the significant impacts on Nash outcomes of endogenizing the Chinese trade surplus in the model in this way.
\end{abstract}

JEL Code: F13.

Keywords: inside money, general equilibrium, Nash equilibrium, numerical analysis, tariff rate.

$\begin{array}{cc}\text { John Whalley } & \text { Jun Yu } \\ \text { Department of Economics } & \text { Department of Finance } \\ \text { University of Western Ontario } & \text { School of Economics } \\ \text { Canada } & \text { Xiamen University } \\ \text { jwhalley@uwo.ca } & \text { P.R. China } \\ \text { Center for Macroeconomic Research and Department of Finance } \\ \text { School of Economics } \\ \text { Xiamen University } \\ \text { P.R. China }\end{array}$

December 13, 2008

We are grateful for financial support from National Social Science Foundation of China 2007 (Grant: 07AJL002) and Major Project "Humanities and Social Science" of Chinese Ministry of Education 2008 (Grant: 07JJD790145). We thank Jim Davies, David Laidler and participants in seminars at University of Western Ontario and Xiamen University for helpful comments. The first author acknowledges support from the Leibnitz Foundation under their "Reinventing Europe" programme at CESifo, Munich. 


\section{Introduction and Background}

We discuss how trade retaliation in monetary trade models differs from trade retaliation in classical goods only barter models as in Johnson (1953), Gorman (1958), Kuga (1973), Hamilton and Whalley (1983) and others. In such models trade surpluses and deficits are endogenously determined and countries with trade deficits (surpluses) typically have more (less) retaliatory power than in models with balanced trade.

Models in which trade takes place geographically across countries and through time in financial assets simultaneously are little explored in the literature. Traditional trade models impose a classical separation between real and monetary sides, while models of inter-temporal exchange usually limit themselves to one good. This is inherently unsatisfactory, however, if one is considering trade policy responses in economies such as the US with a large trade deficit, or China with a large trade surplus. If trade interventions affect the price of intertemporal exchange, optimal policy needs to be appropriately modified. Countries which run large deficits in goods trade will typically have more retaliatory power compared to balanced trade, and countries running surpluses less. Outcomes of Nash tariff games will thus be affected.

We present a simple multi-good multi-country trade model which also captures trade through time in the form of inside money as used in macro literature. Trade through time and space can be thought of as comparable, and inside money (debt) issued by one country will in equilibrium offset inside money (debt) acquired by the other. The equilibrium price of debt will determine an interest factor, which along with the commodity terms of trade can be changed by trade policy interventions. Optimal trade policy for single countries will therefore differ from that in a conventional goods only trade model with balanced trade in goods, and outcomes of Nash tariff games will be similarly affected. If a country runs a trade surplus, their no response optimal tariff is significantly lowered. Comparing trade retaliation within the same framework also allows us to assess Nash equilibria in tariffs between the two countries both with and without the added element of inter-temporal trade.

We show how a monetary trade model can be constructed for the 2 country 2 good case, and, for simplicity, consider a simple pure exchange case. Such a model has no closed form solution, but it can be used for numerical analysis. Model solutions using model specifications calibrated to 2005 Chinese/Rest-of-World (ROW) data are used first to analyze individual country optimal policy in this framework assuming no strategic response from the partner country. Results indicate the additional impacts of considering inside money effects depend upon both country differences in rates of time preference, and the relative size of commodity 
and inter-temporal trade, and the additional effects involved can be substantial.

The conclusion we offer is that in today's world of significant current account surpluses and deficits across large trading entities (U.S., China, for example) using conventional balanced trade (or exogenous trade imbalance) models will typically be misleading as a way to analyze optimal trade policy interventions. Trade deficit countries will typically have higher optimal tariffs and trade surplus countries have lower optimal tariffs than balanced trade models suggest. While models with endogenous trade imbalances may not yield analytical closed form solutions, in numerical simulation work there seems little reason not to use models with such monetary trade interactions. This is especially so when evaluating trade policy options and outcomes of Nash tariff games. 


\section{A Simple 2 Good, 2 Country Trade Model with Inside Money}

We first present a conventional trade model with trade in goods to which monetary structure using inside money is added. This then allows for endogenous determination of trade imbalances for trade in goods, offset through inter-temporal trade in money (or assets).

We build on modern macro-literature (see Azariadis (1993) pages 175 - 180) in which there is extensive use made of simple overlapping generations models with inside money. Trade in commodities, either between individuals or across countries is usually not explicitly included in such macro literature, in part for tractability but in part also due to the focus on intertemporal allocation rather than allocation within periods. But when analyzing trade it is the interaction between monetary structure and commodity trade that is at issue, and models with simultaneous inter-temporal and inter-commodity structure are needed. This is especially the case for analysis of contemporary trade issues currently given the large trade imbalances in economics such as China and the U.S.

In such macro-models there is typically a population of households $H$ which grows geometrically at some rate $n$. There is usually a single consumption good, which must be fully consumed in the period (i.e. no storage is allowed). Each household $h$ is endowed with an amount of the consumption good in each of two periods $E_{y h} \geq 0$ when young, and $E_{o h} \geq 0$ when old.

With no chance to trade endowments, households are limited to autarkic consumption. But if households are relatively patient or relatively well endowed when young, then households are willing to give up consumption when young in return for commitments to be honoured by the next generation's young to repay with consumption in the future. An agreement between two households to exchange consumption between two periods can be thought as a contract which acts as a store of value. The stock of such loans outstanding at any date $t$ is the amount of credit, or inside money.

In these models, if household $h$ has demands for consumption $C_{y h}$ when young and $C_{o h}$ when old, excess demands for consumption at each age, $X_{y h}=C_{y h}-E_{y h}$ and $X_{o h}=C_{o h}-E_{o h}$, are related through the life time budget constraint

$$
X_{y h}+\frac{X_{o h}}{R} \leq 0
$$

where $R$ is the interest factor which applies to loan contracts which exchange one unit of consumption in period $t$ for $R>0$ units of consumption in the next period $(t+1)$.

The debt issued by the young will vary with $R$, and can be written as the negative of their 
excess demands, i.e.

$$
-X_{y h}=S_{h}(R)
$$

where $S_{h}(R)$ represents either saving or accumulation of debt of the young household.

In equilibrium, inter-temporal trades will be generated between young and old households such that in period $t$

$$
C_{y h}^{t}=E_{y h}^{t}-S_{h}(R) \quad \text { and } \quad C_{o h}^{t}=E_{o h}^{t}+R S_{h}(R)
$$

If young and old consumption are gross substitutes (i.e. demand for each dated consumption good is increasing in the price of the other) then all equilibria represented by (3) will be unique.

Following Buiter (1981) this economy can also be generalized to a simple two country (1 and 2) world where countries differ in their rates of time preference. In autarky each economy will be characterized by an interest factor $R_{i}(i=1,2)$. If residents of 2 have higher rates of time preference than those of 1 (i.e. are more patient) then

$$
R_{1}^{A}>R_{2}^{A}
$$

where $R_{1}^{A}$ and $R_{2}^{A}$ represent the loan interest factors in autarky.

In this case with intertemporal trade across countries, there will be a common interest rate $R$ and the relatively impatient young in country 1 will dissave and import goods from country 2 and issue liabilities through commitments to pay interest to foreign residents. In this structure, imports are financed by debt acquired by foreigners.

If growth in the integrated economy occurs at the population growth rate $n$, imports by country $1, M^{1}$, can be written in per capita form as

$$
M^{1}=\left[E_{y}^{1}+\frac{E_{y}^{1}}{1+n}\right]-\left[E_{o}^{1}+\frac{E_{o}^{1}}{1+n}\right]
$$

and the per capita current account deficit can be written as

$$
A^{1}=M^{1}-\frac{R S^{1}}{1+n}
$$

where $S^{1}$ is debt issuance in country 1 and $R$ is the common interest factor between the two countries.

Given that $S^{1}=E_{y}^{1}-C_{y}^{1}$ and $R S^{1}=C_{o}^{1}-E_{o}^{1}$, then

$$
M^{1}=\frac{R-1}{1+n} S^{1}
$$


and $A^{1}=S^{1}$.

In this simple one good economy, the trade imbalance grows at the rate $n$, and the home country is a net importer of goods because in each period the young import more than the old export in order to retire debt.

To develop a multi-commodity trade model with this monetary structure, we could generalize the above to a case where there are two goods in each period and allow inter-commodity trade to co-exist within the period along with trade in debt in the form of inside money. Instead, we simplify things by using a single period model where either claims on future consumption (money holdings) or future consumption liabilities (money issuance) enter the utility function. This is the literature formulation of inside money used by Patinkin (1971), and earlier by Archibald and Lipsey (1958). This also allows for a simpler multi-country model structure with trade in both goods and assets(inside money).

We consider a two country $(i=1,2)$ and two good $(l=1,2)$ pure exchange general equilibrium model in which claims on future consumption enter preferences and are traded between countries. In this, each country has a single representative consumer, with endowments of the two goods $\left(E_{i l} ; i=1,2, l=1,2\right)$ and can either issue or buy claims on future consumption using current period income. For simplicity, we use Cobb-Douglas utility functions

$$
\begin{aligned}
& U_{1}\left(X_{11}, X_{12}, Y_{1}\right)=X_{11}^{\alpha_{11}} X_{12}^{\alpha_{12}} Y_{1}^{\alpha_{13}}, \quad \alpha_{11}+\alpha_{12}+\alpha_{13}=1 \\
& U_{2}\left(X_{21}, X_{22}, Y_{2}\right)=X_{21}^{\alpha_{21}} X_{22}^{\alpha_{22}}\left[Y^{0}-Y_{2}\right]^{\alpha_{23}}, \quad \alpha_{21}+\alpha_{22}+\alpha_{23}=1
\end{aligned}
$$

where $X_{i l}$ denotes the consumption of good $l$ for country $i$ and $\alpha_{i l}$ is the share parameter for good $l$ for country $i$. $Y_{i}$ denotes the inside money for country $i$; in equilibrium $\sum_{i=1}^{2} y_{i}=0$. $y_{i}>0$ represents the issuance of inside money, i.e., the granting of credit to the other country; $y_{i}<0$ denotes the use of credit which must be replayed from future consumption. $Y^{0}$ is a term which can be interpreted as future endowments of consumption for the country that issues credit. We assume $Y^{0}$ is such that $Y^{0}-y_{2}$ is always positive, so that the term is positive in the utility function. This treatment implicitly assumes that the direction of inter-temporal trade is given(country 2 is the issuer of credit and country 1 is the purchaser). This allows for this issuance of inside money by country 2 . This treatment is analogous to assuming the direction of trade in regional trade models, an assumption commonly used in customs union literature (see Abrego, Riezman and Whalley (2003)).

Thus, for any good $l$, we can define the seller's (net of tariff) price as $P_{l}^{0}$ and allow each country $i$ to impose tariffs at rate $T_{i l}$ on each imported $\operatorname{good} l$ (i.e. if $X_{i l} \geq E_{i l}$, then $T_{i l} \geq 0$ ). 
Tariffs are set to zero for any export $i$ (i.e. if $X_{i l} \leq E_{i l}$, then $T_{i l}=0$ ). Internal (gross of tariff) prices for good $l$ in country $i$ are thus

$$
P_{i l}=\left(1+T_{i l}\right) P_{l}^{0}, \quad i=1,2, \quad l=1,2 .
$$

These are also sellers prices of good $l$ in country $i$.

Tariff revenues collected in country $i$ are

$$
R_{i}=\sum_{l=1}^{2} T_{i l} P_{l}^{0}\left(X_{i l}-E_{i l}\right)^{+}, \quad i=1,2
$$

where $E_{i l}$ denotes the initial endowment of good $l$ for country $i$, and the total income of country $i$ is given by

$$
I_{i}=\sum_{l=1}^{2} P_{i l} E_{i l}+R_{i}, \quad i=1,2 .
$$

Budget constraints apply for each country $i$ as

$$
\begin{aligned}
& P_{11} X_{11}+P_{12} X_{12}+P_{0} Y_{1}=I_{1}, \\
& P_{21} X_{21}+P_{22} X_{22}-P_{0} Y_{2}=I_{2} .
\end{aligned}
$$

We next consider utility maximization subject to a budget constraint for each of the two countries. Since there are two different utility functions and two different budget constraints for the two countries, we have to solve the utility maximization problems country by country. Country 1 has a standard Cobb-Douglas utility function and a budget constraint, and the utility maximization problem is as follows.

$$
\begin{array}{ll}
\max & U_{1}\left(X_{11}, X_{12}, Y_{1}\right)=X_{11}^{\alpha_{11}} X_{12}^{\alpha_{12}} Y_{1}^{\alpha_{13}} \\
\text { s.t. } & P_{11} X_{11}+P_{12} X_{12}+P_{0} Y_{1}=I_{1} .
\end{array}
$$

Demands for country 1 (including for future consumption) are

$$
X_{11}=\frac{\alpha_{11} I_{1}}{P_{11}}, \quad X_{12}=\frac{\alpha_{12} I_{1}}{P_{12}}, \quad Y_{1}=\frac{\alpha_{13} I_{1}}{P_{0}} .
$$

For country 2, the utility function is decreasing in inside money since they are the issuers. This is captured by using an upper bound $Y^{0}$ in the utility function in a term $\left[Y^{0}-Y_{2}\right]$. The utility maximization problem in this case is

$$
\begin{array}{ll}
\max & U_{2}\left(X_{21}, X_{22}, Y_{2}\right)=X_{21}^{\alpha_{21}} X_{22}^{\alpha_{22}}\left[Y^{0}-Y_{2}\right]^{\alpha_{23}} \\
\text { s.t. } & P_{21} X_{21}+P_{22} X_{22}-P_{0} Y_{2}=I_{2} .
\end{array}
$$


(2.17) cannot be solved directly, but if use the transformation $y_{2}=Y^{0}-Y_{2}$, then the budget constraint is changed to $P_{21} X_{21}+P_{22} X_{22}-P_{0}\left[Y^{0}-y_{2}\right]=I_{2}$, or

$$
P_{21} X_{21}+P_{22} X_{22}+P_{0} y_{2}=I_{2}+P_{0} Y^{0} \equiv I_{2}^{\prime}
$$

Thus (2.17) can be re-written as

$$
\begin{array}{cl}
\max & U_{2}\left(X_{21}, X_{22}, y_{2}\right)=X_{21}^{\alpha_{21}} X_{22}^{\alpha_{22}} y_{2}^{\alpha_{23}} \\
\text { s.t. } & P_{21} X_{21}+P_{22} X_{22}+P_{0} y_{2}=I_{2}^{\prime} .
\end{array}
$$

Solutions to this problem are

$$
X_{21}=\frac{\alpha_{21} I_{2}^{\prime}}{P_{21}}, \quad X_{22}=\frac{\alpha_{22} I_{2}^{\prime}}{P_{22}}, \quad y_{2}=\frac{\alpha_{23} I_{2}^{\prime}}{P_{0}}
$$

and

$$
Y_{2}=Y^{0}-y_{2}=Y^{0}-\frac{\alpha_{23} I_{2}^{\prime}}{P_{0}}
$$

A general equilibrium for this economy is characterized by a price system $\left(P_{1}^{0}, P_{2}^{0}\right)$ and consumption of goods by countries $\left(X_{i l}: i=1,2 ; l=1,2\right)$ and inside money held or issued by countries $\left(Y_{1}, Y_{2}\right)$ such that market clearing conditions hold:

$$
\begin{aligned}
\sum_{i=1}^{2} X_{i l} & =\sum_{i=1}^{2} E_{i l} \quad \text { for } \quad l=1,2 \\
Y_{1} & =Y_{2}
\end{aligned}
$$

From the solutions (2.16) and (2.20), general equilibrium conditions in the Cobb-Douglas case can be stated as

$$
\begin{gathered}
\frac{\alpha_{11} I_{1}}{P_{11}}+\frac{\alpha_{21}\left[I_{2}+P_{0} Y^{0}\right]}{P_{21}}=E_{11}+E_{21} \\
\frac{\alpha_{12} I_{1}}{P_{12}}+\frac{\alpha_{22}\left[I_{2}+P_{0} Y^{0}\right]}{P_{22}}=E_{12}+E_{22} \\
\frac{\alpha_{13} I_{1}}{P_{0}}=Y^{0}-\frac{\alpha_{23}\left[I_{2}+P_{0} Y^{0}\right]}{P_{0}} .
\end{gathered}
$$

If use CES utility functions

$$
\begin{aligned}
& U_{1}\left(X_{11}, X_{12}, Y_{1}\right)=\left[\alpha_{11}^{\frac{1}{\sigma_{1}}} X_{11}^{\frac{\sigma_{1}-1}{\sigma_{1}}}+\alpha_{12}^{\frac{1}{\sigma_{1}}} X_{12}^{\frac{\sigma_{1}-1}{\sigma_{1}}}+\alpha_{13}^{\frac{1}{\sigma_{1}}} Y_{1}^{\frac{\sigma_{1}-1}{\sigma_{1}}}\right]^{\frac{\sigma_{1}}{\sigma_{1}-1}}, \alpha_{11}+\alpha_{12}+\alpha_{13}=1 \\
& U_{2}\left(X_{21}, X_{22}, Y_{2}\right)=\left[\alpha_{21}^{\frac{1}{\sigma_{2}}} X_{21}^{\frac{\sigma_{2}-1}{\sigma_{2}}}+\alpha_{22}^{\frac{1}{\sigma_{2}}} X_{22}^{\frac{\sigma_{2}-1}{\sigma_{2}}}+\alpha_{23}^{\frac{1}{\sigma_{2}}}\left[Y^{0}-Y_{2}\right]^{\frac{\sigma_{2}-1}{\sigma_{2}}}\right]^{\frac{\sigma_{2}}{\sigma_{2}-1}}, \alpha_{21}+\alpha_{22}+\alpha_{23}=1
\end{aligned}
$$


the solutions to the utility maximization problems are

$$
\begin{aligned}
X_{11} & =\frac{\alpha_{11} I_{1}}{P_{11}^{\sigma_{1}}\left[\sum_{l=1}^{2} \alpha_{1 l} P_{1 l}^{1-\sigma_{1}}+\alpha_{13} P_{0}^{1-\sigma_{1}}\right]} \\
X_{12} & =\frac{\alpha_{12} I_{1}}{P_{12}^{\sigma_{1}}\left[\sum_{l=1}^{2} \alpha_{1 l} P_{1 l}^{1-\sigma_{1}}+\alpha_{13} P_{0}^{1-\sigma_{1}}\right]} \\
Y_{1} & =\frac{\alpha_{13} I_{1}}{P_{0}^{\sigma_{1}}\left[\sum_{l=1}^{2} \alpha_{1 l} P_{1 l}^{1-\sigma_{1}}+\alpha_{13} P_{0}^{1-\sigma_{1}}\right]}
\end{aligned}
$$

and

$$
\begin{aligned}
X_{21} & =\frac{\alpha_{21}\left[I_{2}+P_{0} Y^{0}\right]}{P_{21}^{\sigma_{2}}\left[\sum_{l=1}^{2} \alpha_{2 l} P_{2 l}^{1-\sigma_{2}}+\alpha_{23} P_{0}^{1-\sigma_{2}}\right]} \\
X_{22} & =\frac{\alpha_{22}\left[I_{2}+P_{0} Y^{0}\right]}{P_{22}^{\sigma_{2}}\left[\sum_{l=1}^{2} \alpha_{2 l} P_{2 l}^{1-\sigma_{2}}+\alpha_{23} P_{0}^{1-\sigma_{2}}\right]} \\
y_{2} & =\frac{\alpha_{23}\left[I_{2}+P_{0} Y^{0}\right]}{P_{0}^{\sigma_{2}}\left[\sum_{l=1}^{2} \alpha_{2 l} P_{2 l}^{1-\sigma_{2}}+\alpha_{23} P_{0}^{1-\sigma_{2}}\right]} .
\end{aligned}
$$

General equilibrium conditions in this case are

$$
\begin{gathered}
\frac{\alpha_{11} I_{1}}{P_{11}^{\sigma_{1}}\left[\sum_{l=1}^{2} \alpha_{1 l} P_{1 l}^{1-\sigma_{1}}+\alpha_{13} P_{0}^{1-\sigma_{1}}\right]}+\frac{\alpha_{21}\left[I_{2}+P_{0} Y^{0}\right]}{P_{21}^{\sigma_{2}}\left[\sum_{l=1}^{2} \alpha_{2 l} P_{2 l}^{1-\sigma_{2}}+\alpha_{23} P_{0}^{1-\sigma_{2}}\right]}=E_{11}+E_{21} \\
\frac{\alpha_{12} I_{1}}{P_{12}^{\sigma_{1}}\left[\sum_{l=1}^{2} \alpha_{1 l} P_{1 l}^{1-\sigma_{1}}+\alpha_{13} P_{0}^{1-\sigma_{1}}\right]}+\frac{\alpha_{22}\left[I_{2}+P_{0} Y^{0}\right]}{P_{22}^{\sigma_{2}}\left[\sum_{l=1}^{2} \alpha_{2 l} P_{2 l}^{1-\sigma_{2}}+\alpha_{23} P_{0}^{1-\sigma_{2}}\right]}=E_{12}+E_{22} \\
\frac{\alpha_{13} I_{1}}{P_{0}^{\sigma_{1}}\left[\sum_{l=1}^{2} \alpha_{1 l} P_{1 l}^{1-\sigma_{1}}+\alpha_{13} P_{0}^{1-\sigma_{1}}\right]}=Y^{0}-\frac{\alpha_{23}\left[I_{2}+P_{0} Y^{0}\right]}{P_{0}^{\sigma_{2}}\left[\sum_{l=1}^{2} \alpha_{2 l} P_{2 l}^{1-\sigma_{2}}+\alpha_{23} P_{0}^{1-\sigma_{2}}\right]} .
\end{gathered}
$$

Since we later want to analyze the impacts of adding inside money to model results on optimal trade policy from a conventional pure Barter model, we also consider a comparable no inside money model. Without inside money the model above collapses to a standard simple form. If we use Cobb-Douglas utilities for two countries, then for $i=1,2$,

$$
U_{i}\left(X_{i 1}, X_{i 2}\right)=X_{i 1}^{\alpha_{i 1}} X_{i 2}^{\alpha_{i 2}}, \quad \alpha_{i 1}+\alpha_{i 2}=1
$$

The budget constraints for the two countries are, for $i=1,2$,

$$
P_{i 1} X_{i 1}+P_{i 2} X_{i 2}=I_{i}
$$

and their income for the no inside money case are constructed as

$$
I_{i}=\sum_{l=1}^{2} P_{i l} E_{i l}+R_{i}-B_{i}^{0}, \quad i=1,2 .
$$


where $B_{i}^{0}=\sum_{l=1}^{2} P_{l}^{0} Z_{i l}^{0}$ is trade imbalance from its corresponding case with inside money, which makes trade with and without insie money be comparable. The utility maximization problem for each countries is

$$
\begin{array}{ll}
\max & U_{i}\left(X_{i 1}, X_{i 2}\right)=X_{i 1}^{\alpha_{i 1}} X_{i 2}^{\alpha_{i 2}} \\
\text { s.t. } & P_{i 1} X_{i 1}+P_{i 2} X_{i 2}=I_{i}
\end{array}
$$

and consumptions are

$$
X_{i 1}=\frac{\alpha_{i 1} I_{i}}{P_{i 1}} \quad X_{i 2}=\frac{\alpha_{i 2} I_{i}}{P_{i 2}}
$$

A general equilibrium for this economy is characterized by a world price system $\left(P_{1}^{0}, P_{2}^{0}\right)$ and consumption of goods by countries $\left(X_{i l}: i=1,2 ; l=1,2\right)$ such that markets clear $\sum_{i=1}^{2} X_{i l}=$ $\sum_{i=1}^{2} E_{i l}$ for $l=1,2$.

From (2.42) we can also write general equilibrium conditions as

$$
\begin{aligned}
& \frac{\alpha_{11} I_{1}}{P_{11}}+\frac{\alpha_{21} I_{2}}{P_{21}}=E_{11}+E_{21} \\
& \frac{\alpha_{12} I_{1}}{P_{12}}+\frac{\alpha_{22} I_{2}}{P_{22}}=E_{12}+E_{22} .
\end{aligned}
$$

If we use CES utility functions $U_{i}\left(X_{i 1}, X_{i 2}\right)=\left[\alpha_{i 1}^{\frac{1}{\sigma_{i}}} X_{i 1}^{\frac{\sigma_{i}-1}{\sigma_{i}}}+\alpha_{i 2}^{\frac{1}{\sigma_{i}}} X_{i 2}^{\frac{\sigma_{i}-1}{\sigma_{i}}}\right]^{\frac{\sigma_{1}}{\sigma_{i}-1}}\left(\alpha_{i 1}+\alpha_{i 2}=1\right.$, for $i=1,2)$, then the solution to the utility maximization problem is

$$
X_{i l}=\frac{\alpha_{i l} I_{i}}{P_{i l}^{\sigma_{i}} \sum_{l^{\prime}=1}^{2} \alpha_{i l^{\prime}} P_{i l^{\prime}}^{1-\sigma_{i}}}, \quad i=1,2 \quad l=1,2 .
$$

General equilibrium conditions in this case are

$$
\begin{aligned}
& \frac{\alpha_{11} I_{1}}{P_{11}^{\sigma_{1}} \sum_{l=1}^{2} \alpha_{1 l} P_{1 l}^{1-\sigma_{1}}}+\frac{\alpha_{21} I_{2}}{P_{21}^{\sigma_{2}} \sum_{l=1}^{2} \alpha_{2 l} P_{2 l}^{1-\sigma_{2}}}=E_{11}+E_{21} \\
& \frac{\alpha_{12} I_{1}}{P_{12}^{\sigma_{1}} \sum_{l=1}^{2} \alpha_{1 l} P_{1 l}^{1-\sigma_{1}}}+\frac{\alpha_{22} I_{2}}{P_{22}^{\sigma_{2}} \sum_{l=1}^{2} \alpha_{2 l} P_{2 l}^{1-\sigma_{2}}}=E_{12}+E_{22} .
\end{aligned}
$$

Using these models we can solve the model numerically for Nash equilibria. We assume as in much trade policy literature that the direction of trade in goods is predetermined and that country 1 import goods 1 and export goods 2. This direction of trade is also assumed to be unchanged by tariff interreactions. In computing such equilibria, we also assume that $T_{12}=T_{21}=0$, i.e., tariffs on exported goods are zero. We define a Nash equilibrium for this model as follows. Given $T_{22} \in[0,1]$, we can find $T_{11} \in[0,1]$ such that $U_{1}$ is maximized subject to general equilibrium conditions. Such a value of $T_{11} \in[0,1]$ changes with $T_{22} \in[0,1]$, and it yields country 1 's reaction curve. Given $T_{11} \in[0,1]$, we can also find $T_{22} \in[0,1]$ such that $U_{2}$ 
is maximized subject to general equilibrium conditions hold. Such a value of $T_{22} \in[0,1]$ also changes with $T_{11} \in[0,1]$, and it yields country 2's reaction curve. The intersection of the two country reaction curves then yields the Nash equilibrium.

The central issue to be addressed by the numerical simulation analysis which follows is how different Nash equilibrium outcomes are between the with and without inside money models for similar specifications of preferences and endowments. We use the structures set out above to shed light on this issue. 


\section{Numerical Analysis of China - ROW Optimal Trade Policies}

\subsection{Data and Model Calibration}

We have used the structures set out above to numerically investigate optimal trade policies in a series of model specifications each involving calibration to a base year data set and counterfactual analysis. Given the size of the trade imbalances in the Chinese case we use a two-country (China and ROW) two-good formulation. We use 2005 data and first calibrate the model to observed trade flows and trade imbalances for China. The numerical investigation we report involves computing both own country optimal policy assuming no retaliation from trading partners, as well as cases where retaliatory interplay between countries occurs yielding a Nash equilibrium. We compare outcomes between similar structures with and without the added element of inside money to assess the impact on optimal trade policies of adding monetary structure. We employ GAMS solution software in computing alternative model solutions.

In model calibration we draw on 2005 data from the UNCTAD Handbook of Statistics (2007). In order to use the 2-goods model specification, we divide the value of trade and output in this data into aggregate non-manufacturing and manufacturing sectors for both China and ROW. UNCTAD data on foreign trade report of export and import of primary commodities (including fuels, SITC 0 to 4 plus 68), manufactured goods (SITC 5 to 8 less 68), and services by country. For model 2005 output data we define "agriculture, hunting, forestry, fishing, mining, and utilities" as non-manufacturing from this source, and take "manufacturing and construction" as manufacturing. "Services output" is divided between non-manufacturing and manufacturing sectors with the proportion weighted by sectoral output. We divide import values of service into imports of non-manufactured (primary) and manufactured goods weighted by the import volume of these two sectors. A similar division is made for export values of services.

In using this data in model calibration, we use the benchmark data in value terms and decompose it into price and quantity observations. We define physical units of non-manufacturing and manufacturing products as related to value observations in data following the HarbergerShoven-Whalley units convention that, in the initial benchmark equilibrium data, Buyers prices are gross of country tariffs occurring in base year, Sellers prices are unity, ie $P_{N}=P_{M}=1$.

In the UNCTAD data, the gross output of the Chinese non-manufacturing sector is USD 468.101 billion, compared to an output of USD 11507.699 billion for the ROW. 2005 Manufacturing output of China is USD 1766.189 billion, or $6.0 \%$ of that for ROW, whose 2005 manufacturing output is 29240.343 USD billion. For China, the values of net trade (imports) 
in the non-manufacturing and manufacturing sectors, are 119.943 and -212.955 USD billion, respectively. China is a net importer of non-manufactured goods, and a net exporter of manufactured goods, and in the model data runs a trade surplus of US $\$ 93$ billion in 2005 . The values of sectoral consumption are computed as sectoral output plus the same sectoral net trade.

We use 2005 tariff rates on primary and manufactured goods used by China and ROW from the World Bank (World Development Indicators, 2007) in the benchmark data. 2005 tariff rates are collected from the World Development Indicators (WDI, 2007), and are value weighted by imports. These are different from the simple mean tariffs reported by 2007 World Development Indicators. In calibration we assume both countries impose no tariffs or export subsidies on its exports. In the 2005 data, the value weighted tariff rate of China on primary goods imports is $3.4 \%$, and the value weighted tariff in ROW on imports (manufactured goods) is $3.2 \%$. These different tariff rates yield different relative domestic prices in China and ROW. The total income for each conterpart is computed as its value of output plus the tariff revenue. For China, its 2005 income, $I_{C}$, is US $\$$ billion 2238.368, which is small relative to that of ROW, whose total income, $I_{R}$, is US $\$$ billion 40754.857 .

These data are reported in Table 1 where the model benchmark equilibrium data are shown. The UNCTAD data uses market exchange rates which tend to underestimate real economic activity in China relative to purchasing power parity rates (PPPs). The 2005 International Comparison Program (ICP) of World Bank (2008) employs PPPs measures, and when used yields a different picture. Using 2005 ICP data based on the PPP measure, China's GDP is US\$ 5333.2 billion, and the GDP for ROW is US\$ 49642.5 billion. Using the PPP measure China's share of global GDP is $9.7 \%$, compared to $5.2 \%$ using market exchange rates. Since changes in the relative size of China compared to ROW yield different numerical results from the model, we also calibrate the model to 2005 China and ROW data using PPP data. These are also shown in Table 1.

We can also divide the PPP measured GDP of China and ROW into non-munufacturing and manufacturing sectoral output using the proportion of sectoral output as in the UNCTAD data. The sectoral trade data and tariff rates are the same as the market exchange rate case. In the PPP case, China has output of US\$ 1117.347 billion in the non-manufacturing sector, relative to non-manufacturing output of US\$ 14019.953 billion for ROW. China now accounts for an increased share of global output under the PPP measure, especially in its manufacturing output. In 2005 China produced US $\$ 4215.853$ billion of manufacturing output, $12.2 \%$ of that for ROW, whose manufacturing output are US $\$ 35622.907$ billion. 
As ROW runs a trade deficit and issues inside money in the data, we set their future endowment $Y^{0}$ as (arbitrarily large) to US\$ 1000 billion in calibration. Using 2005 benchmark data from Table 1, we calibrate the share parameters for Cobb-Douglas utility functions for China and ROW. These are reported in Table 2 both for formulations incorporating and excluding inside money. This allows us to assess the added effects of inside money on Nash outcomes. For the case including inside money, China's share parameters in its utility function for non-manufacturing $\left(\alpha_{N}\right)$ and manufacturing goods $\left(\alpha_{M}\right)$ are 0.265 and 0.694 , respectively. In the PPP case, China's share parameters for non-manufacturing $\left(\alpha_{N}\right)$ and manufacturing goods $\left(\alpha_{M}\right)$ are 0.233 and 0.750 respectively. In both two cases, China's share parameters for non-manufacturing goods are lower than those of ROW, which implies that China relatively prefers consumption of manufacturing goods. 


\section{Table 1. Base Case Equilibria Used For Calibration of With Inside Money Models (2005 data in Billion)}

\begin{tabular}{|c|c|c|c|c|}
\hline \multirow{2}{*}{ Value } & \multicolumn{2}{|c|}{ Case Based on Market Exchange Rates } & \multicolumn{2}{c|}{ Case Based on Purchasing Power Parity } \\
\cline { 2 - 5 } & China & ROW & China & ROW \\
\hline \multirow{3}{*}{ Consumption } & $X_{N}=572.653$ & $X_{N}=11387.756$ & $X_{N}=1200.550$ & $X_{N}=13899.649$ \\
& $X_{M}=1553.234$ & $X_{M}=28546.621$ & $X_{M}=4002.898$ & $X_{M}=34731.276$ \\
\hline \multirow{2}{*}{ Endowments } & $E_{N}=452.709$ & $E_{N}=11507.699$ & $E_{N}=1080.607$ & $E_{N}=14019.593$ \\
& $E_{M}=1766.189$ & $E_{M}=28333.666$ & $E_{M}=4215.853$ & $E_{M}=34518.321$ \\
\hline \multirow{2}{*}{ Tariff Rates } & $T_{N}=0.034$ & $T_{N}=0.033$ & $T_{N}=0.034$ & $T_{N}=0.033$ \\
& $T_{M}=0.053$ & $T_{M}=0.032$ & $T_{N}=0.053$ & $T_{N}=0.032$ \\
\hline \multirow{2}{*}{ Imports } & $i_{N}=185.790$ & $i_{N}=65.847$ & $i_{N}=185.790$ & $i_{N}=65.847$ \\
& $i_{M}=555.950$ & $i_{M}=768.905$ & $i_{M}=555.950$ & $i_{M}=768.905$ \\
\hline \multirow{2}{*}{ Exports } & $e_{N}=65.847$ & $e_{N}=185.790$ & $e_{N}=65.847$ & $e_{N}=185.790$ \\
& $e_{M}=768.905$ & $e_{M}=555.950$ & $e_{M}=768.905$ & $e_{M}=555.950$ \\
\hline Trade Imbalance & $B_{C}=93.011$ & $B_{R}=-93.011$ & $B_{C}=93.011$ & $B_{R}=-93.011$ \\
\hline Income & $I_{C}=2238.368$ & $I_{R}=40754.857$ & $I_{C}=5337.278$ & $I_{R}=49649.315$ \\
\hline
\end{tabular}

1. Endowment (Output) and Net Trade data are from Handbook of Statistics(Tables 3.1, 5.2 and 8.3, UNCTAD Handbook of Statistics 2007).

2. "N" denotes Non-Manufacturing section, which include Agriculture, Mining, and Utilities sectors. "M" denotes Manufacturing section which include manufacturing and construction sectors.

3. Tariffs are value weighted and from World Development Indicators (Table 6.7, Tariff Barriers. World Development Indicators 2007).

4. GDP based on PPP measure is from the World Bank (2005 ICP Global Results: Summary Table, page: 23-27, 2005 International Comparison Program).

\section{Table 2. Calibrated Share Parameters - Cobb Douglas Case}

\begin{tabular}{|c|c|c|c|c|}
\hline \multirow{2}{*}{ Share Parameters } & \multicolumn{2}{|c|}{ With Inside Money } & \multicolumn{2}{c|}{ Without Inside Money } \\
\cline { 2 - 5 } & China & ROW & China & ROW \\
\hline CD case based on market exchange rate \\
Non-Manufacturing & $\alpha_{N}=0.264533$ & $\alpha_{N}=0.272729$ & $\alpha_{N}=0.276002$ & $\alpha_{N}=0.278785$ \\
Manufacturing & $\alpha_{M}=0.693914$ & $\alpha_{M}=0.705549$ & $\alpha_{M}=0.723998$ & $\alpha_{M}=0.721215$ \\
Inside Money & $\alpha_{I}=0.041553$ & $\alpha_{I}=0.021722$ & & \\
\hline CD case based on purchasing power parity & & \\
Non-Manufacturing & $\alpha_{N}=0.232585$ & $\alpha_{N}=0.274429$ & $\alpha_{N}=0.236710$ & $\alpha_{N}=0.279433$ \\
Manufacturing & $\alpha_{M}=0.749989$ & $\alpha_{M}=0.707664$ & $\alpha_{M}=0.763290$ & $\alpha_{M}=0.720567$ \\
Inside Money & $\alpha_{I}=0.017427$ & $\alpha_{I}=0.017907$ & \\
\hline
\end{tabular}




\subsection{Model Results}

Using the calibrated model parameters from Table 2, we have conducted several counterfactural numerical analyses using the China-ROW trade model. Table 3 presents model results under various trade policy scenarios for China and ROW. Table 3.1 reports model results for UNCTAD case with inside money, and Table 3.2 for the parallel trade structure excluding inside money. The model results using PPP data with inside money are given in Table 3.3. Table 3.4 reports model PPP results excluding inside money.

The 1st column of Table 3.1 is the 2005 benchmark equilibrium. The result of changing one country's tariff rate assuming no response from the other are reported in Columns 2 and 3 of Table 3.1. In the 2 nd column, when China's tariff rate increases from 0.034 to 0.050 , the world price for China's exports (manufactured goods) relatively rises, and China's income $\left(I_{C}\right)$ increases from 2238.368 to US\$2246.491 billion. However, utility does not increase for China, and is slightly reduced to 1061.107 from 1061.196. In the 3rd column ROW increases its tariffs on imports from the benchmark level of 0.032 to 0.050. Its income also increases but unlike China in Column 2, ROW increases its utility by raising tariffs on imports. The utility of ROW increases from 20614.170 in the benchmark case to 20615.730. This is because ROW is much larger than China in the data and can improve its terms of trade. Thus, if a large country increases tariff rate on its imports, it can reduce its imports and simultaneously lower the world price of imports.

Given tariff rates in one country, we can thus find the optimal tariff rate for the other country. Optimal tariffs for ROW and China respectively are reported in the 4th and 5th column assuming no response from the other country. In the 4th column, the optimal tariff for ROW, $T_{R}$, is 0.3173 when the tariff of China $\left(T_{C}\right)$ remains at 0.0340 . Its utility is increased to 20625.570. In the 5th column, conversely, keeping the tariff of ROW at current levels, we find the optimal rate of China is 0.0131, which is smaller than its applied tariff in 2005. Its utility is slightly increased to 1061.239. These results suggest that, compared to the benchmark case, China would benefit from a small reduction in tariffs on its imports of non-manufactured goods, and the ROW can gain welfare by increasing its import tariffs on manufactured goods.

The last column of Table 3.1 reports the Nash equilibrium of the tariff game between China and ROW. In the Nash equilibrium, the Nash tariffs for China and ROW are $T_{C}=0.0027$ and $T_{R}=0.3346$ respectively, and the amount of inside money is 76.959 . This implies that China should lower its tariff on non-manufacturing imports, and ROW raise its tariffs on imports from China in a Nash equilibrium. In such an equilibrium the trade deficit of ROW and trade 
surplus of China falls.

Comparable analyses using a model structure excluding the added effects of inside money are reported in Table 3.2. The 1st column reports the benchmark equilibrium for the case without inside money, which differs from that in Table 3.1 in income and utility, because incomes are adjusted by initial trade imbalances. Calibration of the no inside money is to this base case data. In the 2nd and 3rd columns, we report results for changes in tariffs of China or ROW alone as in Table 3.1 .

To assess the effects of inside money on optimal tariff policy, we compare the optimal tariffs for China and ROW given tariffs of the other country are fixed at 2005 level. When China's tariff rate fixed at 0.0340 , the 4th column shows that ROW's optimal tariff is 0.0155 , which is lower than that in the case including inside money. The 5th column reports an optimal tariff for China of 0.0016 compared to the optimal tariff rate of 0.0131 in Table 3.1. The Nash equilibrium for a trade structure excluding inside money is reported in the last column. The Nash tariffs for China and ROW are $T_{C}=0.0016$ and $T_{R}=0.0313$, respectively. The country Nash tariff rates are closer compared to the case with inside money. A comparison of outcomes beween Tables 3.1 and 3.2 thus suggests that in terms of retaliating power, acknowledging the role of inside money may benefit countries with a trade deficit, while the country who runs a trade surplus suffers.

Table 3.3 reports model results using PPP data with inside money. The 1st column reports the 2005 benchmark equilibrium for the PPP base case. The 2nd and 3rd columns report equilibrium when China and ROW slightly increase its 2005 tariff rates to 0.05 in turn. In the 2nd column, the world price of manufactured goods remains the same, but the price of nonmanufactured goods is reduced to 0.9987 . The larger asymetric effects on world prices for these 2 goods from the increased tariff of China reveals that, with the much larger size of economy, China's retaliatory tariff power increases. If China's tariff rate increases from 0.034 to 0.050 , the income of China increases from 5337.278 to 5354.553 , but its utility decreases to 2832.890 from 2833.098, and the utility and income of ROW are both reduced. Conversely, when the tariff of the ROW increases to 0.05 , its utility and income increases while China experiences an income and welfare loss. Unlike the results in Table 3.1, the effects on world price of an increase in the tariff of the ROW are less. This reflects the feature that the retaliatory tariff power of the ROW has declined.

Optimal tariff policies for China and ROW are reported in the 4th and 5th columns of Table 3.3, respectively. Given the tariff of China at 0.0340 , the first step optimal tariff of ROW is 
0.1450, which is sharply reduced compared to 0.3174 in Table 3.1. In 5th column, the optimal tariff of China is 0.0140 when the tariff of the ROW is 0.0320 , which shows a slight increase from 0.0131 in Table 3.1. In the Nash equilibrium, the Nash tariffs for China and ROW respectively are 0.0052 and 0.1595 and the gap in optimal tariffs between the 2 countries is narrowed. A comparison of the results in Tables 3.3 and 3.1 suggests that, as a result of much larger size, China has more retaliatory power using the PPPs data relative to the market exchange rate data.

Table 3.4 reports equilibrium outcomes for the PPP case excluding the effects of inside money. The 1st column gives the benchmark equilibrium. In the 2nd column, when the tariff of China unilaterally increases to 0.050 , China's income also increases but not its utility, and the income and utility of ROW both decrease slightly, similar to the results in Tables 3.1, 3.2 and 3.3. The 3rd column reports equilibrium outcomes when the tariff of the ROW increases, and results here yield the same conclusion as Table 3.1. We investigate optimal tariffs for China and ROW in 4th and 5th column. When China's tariff rate fixed at 0.0340, ROW's optimal tariff is 0.0152 , which is lower than that in Table 3.3, and the world price for manufactured goods $P_{M}$ here is 1.0075 , relative to the price of non-manufactured goods $P_{N}=0.9925$. The difference in prices between non-manufactured and manufactured goods decreases compared to the case reported in the Column 4 of Table 3.2. The 5th column reports an optimal tariff for China of 0.0026 , compared to the optimal tariff rate of 0.0140 in Table 3.3.

The last column reports the Nash equilibrium outcome. The Nash tariffs for China and ROW are $T_{C}=0.0028$ and $T_{R}=0.0301$, respectively. The gap in Nash tariffs between the two countries is reduced compared to the case with inside money, and the tariff of ROW is reduced relative to China's, illustrating that inside money helps countries with trade deficits to gain improved retaliatory power.

In brief, the results for both market exchange rate and PPP cases indicates that inside money can exert significant influence on retaliatory power. Specifically, the large economies with trade deficits gain improved retaliatory power in a tariff war. 
Table 3. Equilibria in Trade between China

and the ROW with and without Inside Money

\subsection{Equilibrium with Inside Money (Market Exchange Rate Data)}

\begin{tabular}{|c|c|c|c|c|c|c|}
\hline & $\begin{array}{l}\text { Benchmark } \\
\text { Equilibrium }\end{array}$ & $\begin{array}{c}\text { Equilibrium } \\
\text { with } 5 \% \\
\text { Tariff from } \\
\text { China }\end{array}$ & $\begin{array}{c}\text { Equilibrium } \\
\text { with } 5 \% \\
\text { Tariff from } \\
\text { ROW } \\
\end{array}$ & $\begin{array}{l}\text { Optimal Tariff } \\
\text { Rate Given } \\
\text { Tariff from } \\
\text { China }\end{array}$ & $\begin{array}{l}\text { Optimal Tariff } \\
\text { Rate Given } \\
\text { Tariff from } \\
\text { ROW }\end{array}$ & $\begin{array}{c}\text { Nash } \\
\text { Equilibrium }\end{array}$ \\
\hline Tariff Rate & $\begin{array}{l}T_{C}=0.0340 \\
T_{R}=0.0320\end{array}$ & $\begin{array}{l}T_{C}=0.0500 \\
T_{R}=0.0320\end{array}$ & $\begin{array}{l}T_{C}=0.0340 \\
T_{R}=0.0500\end{array}$ & $\begin{array}{l}T_{C}=0.0340 \\
T_{R}=0.3173\end{array}$ & $\begin{array}{l}T_{C}=0.0131 \\
T_{R}=0.0320\end{array}$ & $\begin{array}{l}T_{C}=0.0027 \\
T_{R}=0.3346\end{array}$ \\
\hline Price & $\begin{array}{c}P_{N}=1.0000 \\
P_{M}=1.0000 \\
P_{0}=1\end{array}$ & $\begin{array}{c}P_{N}=0.9991 \\
P_{M}=0.9998 \\
P_{0}=1\end{array}$ & $\begin{array}{c}P_{N}=1.0006 \\
P_{M}=0.9843 \\
P_{0}=1\end{array}$ & $\begin{array}{c}P_{N}=1.0079 \\
P_{M}=0.7985 \\
P_{0}=1\end{array}$ & $\begin{array}{c}P_{N}=1.0012 \\
P_{M}=1.0002 \\
P_{0}=1\end{array}$ & $\begin{array}{c}P_{N}=1.0098 \\
P_{M}=0.7890 \\
P_{0}=1\end{array}$ \\
\hline Consumption & $\begin{array}{c}X_{C N}=572.653 \\
X_{C M}=1553.234 \\
X_{R N}=11387.760 \\
X_{R M}=28546.620 \\
Y=93.011\end{array}$ & $\begin{array}{c}X_{C N}=566.490 \\
X_{C M}=1559.129 \\
X_{R N}=11393.920 \\
X_{R M}=28540.730 \\
Y=93.349\end{array}$ & $\begin{aligned} X_{C N} & =565.214 \\
X_{C M} & =1558.492 \\
X_{R N} & =11395.190 \\
X_{R M} & =28541.360 \\
Y & =91.859\end{aligned}$ & $\begin{aligned} X_{C N} & =477.960 \\
X_{C M} & =1636.330 \\
X_{R N} & =11482.450 \\
X_{R M} & =28463.530 \\
Y & =78.244\end{aligned}$ & $\begin{array}{c}X_{C N}=580.916 \\
X_{C M}=1545.317 \\
X_{R N}=11379.490 \\
X_{R M}=28554.540 \\
Y=92.558\end{array}$ & $\begin{array}{c}X_{C N}=483.861 \\
X_{C M}=1628.785 \\
X_{R N}=11476.550 \\
X_{R M}=28471.070 \\
Y=76.959\end{array}$ \\
\hline Income & $\begin{array}{l}I_{C}=2238.368 \\
I_{R}=40754.860\end{array}$ & $\begin{array}{l}I_{C}=2246.491 \\
I_{R}=40739.320\end{array}$ & $\begin{array}{l}I_{C}=2210.653 \\
I_{R}=40807.880\end{array}$ & $\begin{array}{c}I_{C}=1882.996 \\
I_{R}=41434.670\end{array}$ & $\begin{array}{l}I_{C}=2227.454 \\
I_{R}=40775.740\end{array}$ & $\begin{array}{l}I_{C}=1852.068 \\
I_{R}=41493.840\end{array}$ \\
\hline Utility & $\begin{array}{l}U_{C}=1061.196 \\
U_{R}=20614.170\end{array}$ & $\begin{array}{l}U_{C}=1061.107 \\
U_{R}=20614.040\end{array}$ & $\begin{array}{l}U_{C}=1059.466 \\
U_{R}=20615.730\end{array}$ & $\begin{array}{l}U_{C}=1041.396 \\
U_{R}=20625.570\end{array}$ & $\begin{array}{l}U_{C}=1061.239 \\
U_{R}=20614.350\end{array}$ & $\begin{aligned} U_{C} & =1040.720 \\
U_{R} & =20627.160\end{aligned}$ \\
\hline
\end{tabular}

\subsection{Equilibrium without Inside Money (Market Exchange Rate Data)}

\begin{tabular}{|c|c|c|c|c|c|c|}
\hline & $\begin{array}{l}\text { Benchmark } \\
\text { Equilibrium }\end{array}$ & $\begin{array}{l}\text { Equilibrium } \\
\text { with } 5 \% \\
\text { Tariff from } \\
\text { China }\end{array}$ & $\begin{array}{c}\text { Equilibrium } \\
\text { with } 5 \% \\
\text { Tariff from } \\
\text { ROW }\end{array}$ & $\begin{array}{l}\text { Optimal tariff } \\
\text { Rate Given } \\
\text { tariff from } \\
\text { China }\end{array}$ & $\begin{array}{l}\text { Optimal Tariff } \\
\text { Rate Given } \\
\text { Tariff from } \\
\text { ROW }\end{array}$ & $\begin{array}{l}\text { Nash } \\
\text { Equilibrium }\end{array}$ \\
\hline Tariff Rate & $\begin{array}{l}T_{C}=0.0340 \\
T_{R}=0.0320\end{array}$ & $\begin{array}{l}T_{C}=0.0500 \\
T_{R}=0.0320\end{array}$ & $\begin{array}{l}T_{C}=0.0340 \\
T_{R}=0.0500\end{array}$ & $\begin{array}{l}T_{C}=0.0340 \\
T_{R}=0.0155\end{array}$ & $\begin{aligned} T_{C} & =0.0016 \\
T_{R} & =0.0320\end{aligned}$ & $\begin{array}{l}T_{C}=0.0016 \\
T_{R}=0.0313\end{array}$ \\
\hline World Price & $\begin{array}{l}P_{N}=1.0000 \\
P_{M}=1.0000\end{array}$ & $\begin{array}{l}P_{N}=0.9996 \\
P_{M}=1.0004\end{array}$ & $\begin{array}{l}P_{N}=1.0082 \\
P_{M}=0.9918\end{array}$ & $\begin{array}{l}P_{N}=0.9923 \\
P_{M}=1.0077\end{array}$ & $\begin{array}{l}P_{N}=1.0008 \\
P_{M}=0.9992\end{array}$ & $\begin{array}{l}P_{N}=1.0005 \\
P_{M}=0.9995\end{array}$ \\
\hline Consumption & $\begin{array}{l}X_{C N}=572.653 \\
X_{C M}=1553.234 \\
X_{R N}=11387.760 \\
X_{R M}=28546.620\end{array}$ & $\begin{array}{l}X_{C N}=566.561 \\
X_{C M}=1559.322 \\
X_{R N}=11393.850 \\
X_{R M}=28540.530\end{array}$ & $\begin{array}{l}X_{C N}=565.827 \\
X_{C M}=1560.173 \\
X_{R N}=11394.580 \\
X_{R M}=28539.680\end{array}$ & $\begin{array}{l}X_{C N}=579.126 \\
X_{C M}=1546.859 \\
X_{R N}=11381.280 \\
X_{R M}=28553.000\end{array}$ & $\begin{array}{l}X_{C N}=585.412 \\
X_{C M}=1540.455 \\
X_{R N}=11375.000 \\
X_{R M}=28559.400\end{array}$ & $\begin{array}{l}X_{C N}=585.676 \\
X_{C M}=1540.199 \\
X_{R N}=11374.730 \\
X_{R M}=28559.660\end{array}$ \\
\hline Income & $\begin{array}{l}I_{C}=2145.357 \\
I_{R}=40847.870\end{array}$ & $\begin{array}{l}I_{C}=2154.569 \\
I_{R}=40854.400\end{array}$ & $\begin{array}{l}I_{C}=2137.218 \\
I_{R}=41208.500\end{array}$ & $\begin{array}{l}I_{C}=2152.953 \\
I_{R}=40511.260\end{array}$ & $\begin{array}{l}I_{C}=2126.037 \\
I_{R}=40834.100\end{array}$ & $\begin{array}{l}I_{C}=2126.372 \\
I_{R}=40819.970\end{array}$ \\
\hline Utility & $\begin{array}{l}U_{C}=1179.323 \\
U_{R}=22094.650\end{array}$ & $\begin{array}{l}U_{C}=1179.181 \\
U_{R}=22094.550\end{array}$ & $\begin{array}{l}U_{C}=1179.226 \\
U_{R}=22094.470\end{array}$ & $\begin{array}{l}U_{C}=1179.470 \\
U_{R}=22094.710\end{array}$ & $\begin{array}{l}U_{C}=1179.441 \\
U_{R}=22094.880\end{array}$ & $\begin{aligned} U_{C} & =1179.446 \\
U_{R} & =22094.880\end{aligned}$ \\
\hline
\end{tabular}


3.3 Equilibrium with Inside Money (Purchasing Power Parity Data)

\begin{tabular}{|c|c|c|c|c|c|c|}
\hline & $\begin{array}{l}\text { Benchmark } \\
\text { Equilibrium }\end{array}$ & $\begin{array}{l}\text { Equilibrium } \\
\text { with } 5 \% \\
\text { Tariff from } \\
\text { China }\end{array}$ & $\begin{array}{c}\text { Equilibrium } \\
\text { with } 5 \% \\
\text { Tariff from } \\
\text { ROW }\end{array}$ & $\begin{array}{l}\text { Optimal Tariff } \\
\text { Rate Given } \\
\text { Tariff from } \\
\text { China }\end{array}$ & $\begin{array}{l}\text { Optimal Tariff } \\
\text { Rate Given } \\
\text { Tariff from } \\
\text { ROW }\end{array}$ & $\begin{array}{l}\text { Nash } \\
\text { Equilibrium }\end{array}$ \\
\hline Tariff Rate & $\begin{array}{l}T_{C}=0.0340 \\
T_{R}=0.0320\end{array}$ & $\begin{array}{l}T_{C}=0.0500 \\
T_{R}=0.0320\end{array}$ & $\begin{array}{l}T_{C}=0.0340 \\
T_{R}=0.0500\end{array}$ & $\begin{array}{l}T_{C}=0.0340 \\
T_{R}=0.1450\end{array}$ & $\begin{array}{l}T_{C}=0.0140 \\
T_{R}=0.0320\end{array}$ & $\begin{array}{l}T_{C}=0.0052 \\
T_{R}=0.1595\end{array}$ \\
\hline Price & $\begin{array}{c}P_{N}=1.0000 \\
P_{M}=1.0000 \\
P_{0}=1\end{array}$ & $\begin{array}{c}P_{N}=0.9987 \\
P_{M}=1.0000 \\
P_{0}=1\end{array}$ & $\begin{array}{c}P_{N}=1.0002 \\
P_{M}=0.9845 \\
P_{0}=1\end{array}$ & $\begin{array}{c}P_{N}=1.0011 \\
P_{M}=0.9100 \\
P_{0}=1\end{array}$ & $\begin{array}{c}P_{N}=1.0016 \\
P_{M}=1.0000 \\
P_{0}=1\end{array}$ & $\begin{array}{c}P_{N}=1.0034 \\
P_{M}=0.8996 \\
P_{0}=1\end{array}$ \\
\hline Consumption & $\begin{aligned} X_{C N} & =1200.550 \\
X_{C M} & =4002.898 \\
X_{R N} & =13899.650 \\
X_{R M} & =34731.280 \\
Y & =93.011\end{aligned}$ & $\begin{array}{c}X_{C N}=1187.583 \\
X_{C M}=4015.706 \\
X_{R N}=13912.620 \\
X_{R M}=34718.470 \\
Y=93.312\end{array}$ & $\begin{array}{c}X_{C N}=1185.536 \\
X_{C M}=4015.934 \\
X_{R N}=13914.660 \\
X_{R M}=34718.240 \\
Y=91.865\end{array}$ & $\begin{aligned} X_{C N} & =1113.666 \\
X_{C M} & =4084.578 \\
X_{R N} & =13986.530 \\
X_{R M} & =34649.600 \\
Y & =86.372\end{aligned}$ & $\begin{array}{c}X_{C N}=1217.162 \\
X_{C M}=3986.440 \\
X_{R N}=13883.040 \\
X_{R M}=34747.730 \\
Y=92.624\end{array}$ & $\begin{array}{c}X_{C N}=1125.974 \\
X_{C M}=4070.666 \\
X_{R N}=13974.230 \\
X_{R M}=34663.510 \\
Y=85.087\end{array}$ \\
\hline Income & $\begin{array}{l}I_{C}=5337.278 \\
I_{R}=49649.310\end{array}$ & $\begin{array}{l}I_{C}=5354.553 \\
I_{R}=49632.500\end{array}$ & $\begin{array}{l}I_{C}=5271.497 \\
I_{R}=49713.330\end{array}$ & $\begin{array}{l}I_{C}=4956.280 \\
I_{R}=50020.090\end{array}$ & $\begin{array}{l}I_{C}=5315.082 \\
I_{R}=49670.910\end{array}$ & $\begin{array}{l}I_{C}=4882.580 \\
I_{R}=50091.810\end{array}$ \\
\hline Utility & $\begin{array}{l}U_{C}=2833.098 \\
U_{R}=25306.170\end{array}$ & $\begin{array}{l}U_{C}=2832.890 \\
U_{R}=25305.890\end{array}$ & $\begin{array}{l}U_{C}=2831.103 \\
U_{R}=25307.510\end{array}$ & $\begin{array}{l}U_{C}=2822.880 \\
U_{R}=25310.580\end{array}$ & $\begin{array}{l}U_{C}=2833.194 \\
U_{R}=25306.540\end{array}$ & $\begin{array}{l}U_{C}=2822.136 \\
U_{R}=25312.290\end{array}$ \\
\hline
\end{tabular}

\subsection{Equilibrium without Inside Money (Purchasing Power Parity Data)}

\begin{tabular}{|c|c|c|c|c|c|c|}
\hline & $\begin{array}{l}\text { Benchmark } \\
\text { Equilibrium }\end{array}$ & $\begin{array}{c}\text { Equilibrium } \\
\text { with } 5 \% \\
\text { Tariff from } \\
\text { China } \\
\end{array}$ & $\begin{array}{c}\text { Equilibrium } \\
\text { with } 5 \% \\
\text { Tariff from } \\
\text { ROW } \\
\end{array}$ & $\begin{array}{l}\text { Optimal tariff } \\
\text { Rate Given } \\
\text { tariff from } \\
\text { China }\end{array}$ & $\begin{array}{l}\text { Optimal Tariff } \\
\text { Rate Given } \\
\text { Tariff from } \\
\text { ROW } \\
\end{array}$ & $\begin{array}{l}\text { Nash } \\
\text { Equilibrium }\end{array}$ \\
\hline Tariff Rate & $\begin{array}{l}T_{C}=0.0340 \\
T_{R}=0.0320\end{array}$ & $\begin{array}{l}T_{C}=0.0500 \\
T_{R}=0.0320\end{array}$ & $\begin{array}{l}T_{C}=0.0340 \\
T_{R}=0.0500\end{array}$ & $\begin{array}{l}T_{C}=0.0340 \\
T_{R}=0.0152\end{array}$ & $\begin{array}{l}T_{C}=0.0026 \\
T_{R}=0.0320\end{array}$ & $\begin{array}{l}T_{C}=0.0028 \\
T_{R}=0.0301\end{array}$ \\
\hline World Price & $\begin{array}{l}P_{N}=1.0000 \\
P_{M}=1.0000\end{array}$ & $\begin{array}{l}P_{N}=0.9993 \\
P_{M}=1.0007\end{array}$ & $\begin{array}{l}P_{N}=1.0079 \\
P_{M}=0.9921\end{array}$ & $\begin{array}{l}P_{N}=0.9925 \\
P_{M}=1.0075\end{array}$ & $\begin{array}{l}P_{N}=1.0013 \\
P_{M}=0.9987\end{array}$ & $\begin{array}{l}P_{N}=1.0005 \\
P_{M}=0.9995\end{array}$ \\
\hline Consumption & $\begin{array}{l}X_{C N}=1200.550 \\
X_{C M}=4002.898 \\
X_{R N}=13899.650 \\
X_{R M}=34731.280\end{array}$ & $\begin{array}{l}X_{C N}=1187.616 \\
X_{C M}=4015.815 \\
X_{R N}=13912.580 \\
X_{R M}=34718.360\end{array}$ & $\begin{array}{l}X_{C N}=1186.050 \\
X_{C M}=4017.629 \\
X_{R N}=13914.150 \\
X_{R M}=34716.540\end{array}$ & $\begin{array}{l}X_{C N}=1214.552 \\
X_{C M}=3989.105 \\
X_{R N}=13885.650 \\
X_{R M}=34745.070\end{array}$ & $\begin{array}{l}X_{C N}=1226.732 \\
X_{C M}=3976.647 \\
X_{R N}=13873.470 \\
X_{R M}=34757.530\end{array}$ & $\begin{array}{l}X_{C N}=1228.188 \\
X_{C M}=3975.234 \\
X_{R N}=13872.010 \\
X_{R M}=34758.940\end{array}$ \\
\hline Income & $\begin{array}{l}I_{C}=5244.267 \\
I_{R}=49742.330\end{array}$ & $\begin{array}{l}I_{C}=5264.613 \\
I_{R}=49756.180\end{array}$ & $\begin{array}{l}I_{C}=5221.920 \\
I_{R}=50188.200\end{array}$ & $\begin{array}{l}I_{C}=5265.515 \\
I_{R}=49318.370\end{array}$ & $\begin{array}{l}I_{C}=5202.996 \\
I_{R}=49714.190\end{array}$ & $\begin{array}{l}I_{C}=5205.566 \\
I_{R}=49666.850\end{array}$ \\
\hline Utility & $\begin{array}{l}U_{C}=3010.071 \\
U_{R}=26889.670\end{array}$ & $\begin{array}{l}U_{C}=3009.755 \\
U_{R}=26889.450\end{array}$ & $\begin{array}{l}U_{C}=3009.853 \\
U_{R}=26889.290\end{array}$ & $\begin{array}{l}U_{C}=3010.402 \\
U_{R}=26889.790\end{array}$ & $\begin{array}{l}U_{C}=3010.325 \\
U_{R}=26890.140\end{array}$ & $\begin{array}{l}U_{C}=3010.354 \\
U_{R}=26890.140\end{array}$ \\
\hline
\end{tabular}


We also present results which show the impacts of model behavior of using CES rather than CD preferences in Table 4. The 1st and 2nd columns report the Nash tariffs for the market exchange rate case with and without inside money. The 3rd and 4th columns report Nash tariffs for the PPP case with and without the added effects of inside money. The Cobb-Douglas case reported in Table 3 is presented here to allow comparison to results from CES cases. The 2nd to the 5th rows report the Nash equilibrium outcome from CES formulations with different elasticities of substitution of $\left(\sigma_{C}=0.80 ; \sigma_{R}=1.25\right),\left(\sigma_{C}=1.25 ; \sigma_{R}=0.80\right),\left(\sigma_{C}=0.80\right.$; $\left.\sigma_{R}=0.80\right)$ and $\left(\sigma_{C}=1.25 ; \sigma_{R}=1.25\right)$ respectively. The 6 th to 9 th rows present the Nash equilibrium in CES cases with elasticities of substitution of $\left(\sigma_{C}=0.50 ; \sigma_{R}=2.00\right),\left(\sigma_{C}=2.00\right.$; $\left.\sigma_{R}=0.50\right),\left(\sigma_{C}=0.50 ; \sigma_{R}=0.50\right)$ and $\left(\sigma_{C}=2.00 ; \sigma_{R}=2.00\right)$, respectively. In these CES formulations, Nash tariffs change with the elasticities of substitution, since preferences also have an impact on tariff outcomes.

We first examine Nash tariffs across the first 4 CES preference cases for the market exchange rate case with inside money. The ratio of Nash tariffs for ROW to China is the largest with elasticities of substitution of $\left(\sigma_{C}=0.80 ; \sigma_{R}=1.25\right)$, and the Nash tariffs are 0.0016 and 0.4279 respectively for China and ROW. The ratio of Nash tariffs is the smallest with elasticities of substitution of $\left(\sigma_{C}=1.25 ; \sigma_{R}=0.80\right)$, and Nash tariffs for China and ROW are $T_{C}=0.0043$ and $T_{R}=0.2666$ respectively. Compared to the first 4 CES cases, the last 4 CES cases have more extremely elasticities of substitution. In these cases, the ratio of the Nash tariff for ROW to China is the largest in case with elasticities of substitution of $\left(\sigma_{C}=0.50 ; \sigma_{R}=2.00\right)$, and Nash tariffs for China and ROW are 0.0003 and 0.7633 respectively. In the 6th row, China's preference is relatively less flexible compared to the case reported in the 2nd row. The opposite is the case with elasticities of substitution of $\left(\sigma_{C}=2.00 ; \sigma_{R}=0.50\right)$, where the Nash tariffs of China and ROW are 0.0113 and 0.1762 , respectively. Compared to results reported in the 3rd row of the preference of China become more flexible relative to ROW, China has improved retaliatory power compared to ROW in a tariff war.

The Nash tariff results in these CES cases suggest that more rigid consumer preferences result in lower retaliatory power, and flexible preferences yield economies relatively larger negotiating power. The intuition is that one country can make advantage of the much rigid preferences of its counterpart to exploit welfare gains.

Table 5 reports comparisons of impacts on trade volumes and imbalances between Nash equilibria, the benchmark equilibrium and a no tariff equilibrium in CD cases with and without inside money. The first subtabulation reports the value of net imports by country, and the 
second reports the size of trade imbalances (or inside money) in these 3 equilibrium. In free trade with inside money, China's net imports are US\$147.800 billion, compared to US\$242.193 billion for ROW, and their trade imbalance is US\$ 94.393 billion. In the Nash equilibrium with inside money, net imports of China and ROW are reduced to US $\$ 31.457$ billion and 76.959 billion respectively. The amount of inside money in Nash equilibrium falls to US\$ 76.959 billion. In the CD formulation without inside money, both countries have balanced trade, and their net trade is offset by the initial trade imbalance in the base case data. In the free trade equilibrium, the amount of net trade of China is US\$ 144.267 billion, and ROW's is US\$241.988 billion. In the benchmark equilibrium, the net imports of China and ROW are US\$119.943 billion and 212.954 billion, respectively. In the Nash equilibrium, countries trade decreases relative to the base case, and their net imports are $i_{C}=133.028$ and $i_{R}=225.890$. The trade data across alternative cases implies that the benchmark equilibrium is far from the Nash equilibrium case, while the free trade equilibrium case is closer to it.

Finally we investigate the influence of the size of future endowments on Nash equilibrium outcomes. As presented in Table 6, we can examine the effects on Nash tariffs, world prices, utilities, and the amount of inside money of changing $Y^{0}$ from 700 to 5000 with a step size of 100. Results show that as the future endowment of the ROW increases, the Nash tariffs of both sides increase slightly, together with the downward prices, utilities and the amount of inside money. 
Table 4. Sensitivity of Nash Equilibrium Tariffs to Elasticities of Substitution

\begin{tabular}{|c|c|c|c|c|}
\hline & \multicolumn{2}{|c|}{$\begin{array}{c}\text { Cases Based on } \\
\text { Market Exchange Rates }\end{array}$} & \multicolumn{2}{|c|}{$\begin{array}{c}\text { Cases Based on } \\
\text { Purchasing Power Parity Rates }\end{array}$} \\
\hline & $\begin{array}{l}\text { Nash Tariffs } \\
\text { With } \\
\text { Inside Money }\end{array}$ & $\begin{array}{l}\text { Nash Tariffs } \\
\text { Without } \\
\text { Inside Money }\end{array}$ & $\begin{array}{l}\text { Nash Tariffs } \\
\text { With } \\
\text { Inside Money }\end{array}$ & $\begin{array}{l}\text { Nash Tariffs } \\
\text { Without } \\
\text { Inside Money }\end{array}$ \\
\hline \multicolumn{5}{|c|}{ 1. Cobb-Douglas case } \\
\hline China & $T_{C}=0.0027$ & $T_{C}=0.0016$ & $T_{C}=0.0052$ & $T_{C}=0.0028$ \\
\hline ROW & $T_{R}=0.3346$ & $T_{R}=0.0313$ & $T_{R}=0.1595$ & $T_{R}=0.0301$ \\
\hline \multicolumn{5}{|c|}{ 2. CES case with elasticities of substitution $\left(\sigma_{C}=0.80 ; \sigma_{R}=1.25\right)$} \\
\hline China & $T_{C}=0.0016$ & $T_{C}=0.0011$ & $T_{C}=0.0037$ & $T_{C}=0.0019$ \\
\hline ROW & $T_{R}=0.4279$ & $T_{R}=0.0330$ & $T_{R}=0.1957$ & $T_{R}=0.0321$ \\
\hline \multicolumn{5}{|c|}{ 3. CES case with elasticities of substitution $\left(\sigma_{C}=1.25 ; \sigma_{R}=0.80\right)$} \\
\hline China & $T_{C}=0.0043$ & $T_{C}=0.0025$ & $T_{C}=0.0075$ & $T_{C}=0.0042$ \\
\hline ROW & $T_{R}=0.2666$ & $T_{R}=0.0310$ & $T_{R}=0.1325$ & $T_{R}=0.0292$ \\
\hline \multicolumn{5}{|c|}{ 4. CES case with elasticities of substitution $\left(\sigma_{C}=0.80 ; \sigma_{R}=0.80\right)$} \\
\hline China & $T_{C}=0.0030$ & $T_{C}=0.0020$ & $T_{C}=0.0064$ & $T_{C}=0.0035$ \\
\hline ROW & $T_{R}=0.4388$ & $T_{R}=0.0394$ & $T_{R}=0.2044$ & $T_{R}=0.0378$ \\
\hline \multicolumn{5}{|c|}{ 5. CES case with elasticities of substitution $\left(\sigma_{C}=1.25 ; \sigma_{R}=1.25\right)$} \\
\hline China & $T_{C}=0.0023$ & $T_{C}=0.0013$ & $T_{C}=0.0042$ & $T_{C}=0.0022$ \\
\hline ROW & $T_{R}=0.2577$ & $T_{R}=0.0250$ & $T_{R}=0.1251$ & $T_{R}=0.0240$ \\
\hline \multicolumn{5}{|c|}{ 6. CES case with elasticities of substitution $\left(\sigma_{C}=0.50 ; \sigma_{R}=2.00\right)$} \\
\hline China & $T_{C}=0.0003$ & $T_{C}=0.0005$ & $T_{C}=0.0019$ & $T_{C}=0.0009$ \\
\hline ROW & $T_{R}=0.7633$ & $T_{R}=0.0417$ & $T_{R}=0.3184$ & $T_{R}=0.0413$ \\
\hline \multicolumn{5}{|c|}{ 7. CES case with elasticities of substitution $\left(\sigma_{C}=2.00 ; \sigma_{R}=0.50\right)$} \\
\hline China & $T_{C}=0.0113$ & $T_{C}=0.0069$ & $T_{C}=0.0171$ & $T_{C}=0.0110$ \\
\hline ROW & $T_{R}=0.1762$ & $T_{R}=0.0334$ & $T_{R}=0.0954$ & $T_{R}=0.0292$ \\
\hline \multicolumn{5}{|c|}{ 8. CES case with elasticities of substitution $\left(\sigma_{C}=0.50 ; \sigma_{R}=0.50\right)$} \\
\hline China & $T_{C}=0.0028$ & $T_{C}=0.0032$ & $T_{C}=0.0097$ & $T_{C}=0.0056$ \\
\hline ROW & $T_{R}=0.8121$ & $T_{R}=0.0639$ & $T_{R}=0.3526$ & $T_{R}=0.0614$ \\
\hline \multicolumn{5}{|c|}{ 9. CES case with elasticities of substitution $\left(\sigma_{C}=2.00 ; \sigma_{R}=2.00\right)$} \\
\hline China & $T_{C}=0.0016$ & $T_{C}=0.0008$ & $T_{C}=0.0027$ & $T_{C}=0.0014$ \\
\hline ROW & $T_{R}=0.1522$ & $T_{R}=0.0155$ & $T_{R}=0.0759$ & $T_{R}=0.0149$ \\
\hline
\end{tabular}


Table 5. Comparisons of Trade Volumes and Trade Imbalances between Nash Equilibria, Base Case and Free Trade for Cobb-Douglas Case

\begin{tabular}{|c|c|c|c|}
\hline & & $\begin{array}{c}\text { With Inside } \\
\text { Money }\end{array}$ & $\begin{array}{c}\text { Without Inside } \\
\text { Money }\end{array}$ \\
\hline Impacts on Trade Volumes (at constant base case prices) \\
China's Imports & Base Case & $i_{C}=119.943451$ & $i_{C}=119.943451$ \\
& Free Trade & $i_{C}=147.800109$ & $i_{C}=144.267297$ \\
\hline \multirow{4}{*}{ ROW's Imports } & Nash Equilibrium & $i_{R}=108.416846$ & $i_{R}=225.889704$ \\
& Base Case & $i_{R}=212.954663$ & $i_{R}=212.953912$ \\
Impacts on Trade Imbalances (in billion USD) & $i_{R}=241.987682$ \\
\hline \multirow{3}{*}{ China's Trade Surplus } & Free Trade & $i_{R}=242.192954$ & $i_{R}$ \\
& Nash Equilibrium & $B_{C}=76.959162$ & $B_{C}=0$ \\
& Base Case & $B_{C}=93.011138$ & $B_{C}=0$ \\
\hline \multirow{2}{*}{ FOW's Trade Deficit Trade } & $B_{C}=94.393381$ & $B_{C}=0$ \\
\hline & Nash Equilibrium & $B_{R}=-76.959162$ & $B_{R}=0$ \\
& Base Case & $B_{R}=-93.011138$ & $B_{R}=0$ \\
& Free Trade & $B_{R}=-94.393381$ & $B_{R}=0$ \\
\hline
\end{tabular}


Table 6. Sensitivity of Nash Equilibrium to $Y^{0}$

\begin{tabular}{|c|c|c|c|c|}
\hline Future Endowments $\left(Y^{0}\right)$ & Nash Tariffs & World Price & Utility & Inside Money \\
\hline \multirow{2}{*}{700} & $T_{C}=0.0008$ & $P_{N}=1.0176$ & $U_{C}=1041.144$ & $Y=77.599$ \\
\hline & $T_{R}=0.3324$ & $P_{M}=0.7963$ & $U_{R}=20974.910$ & \\
\hline \multirow{2}{*}{800} & $T_{C}=0.0016$ & $P_{N}=1.0143$ & $U_{C}=1040.967$ & $Y=77.331$ \\
\hline & $T_{R}=0.3333$ & $P_{M}=0.7933$ & $U_{R}=20850.970$ & \\
\hline \multirow{2}{*}{900} & $T_{C}=0.0022$ & $P_{N}=1.0118$ & $U_{C}=1040.830$ & $Y=77.124$ \\
\hline & $T_{R}=0.3340$ & $P_{M}=0.7909$ & $U_{R}=20735.410$ & \\
\hline \multirow{2}{*}{1000} & $T_{C}=0.0027$ & $P_{N}=1.0098$ & $U_{C}=1040.720$ & $Y=76.959$ \\
\hline & $T_{R}=0.3346$ & $P_{M}=0.7890$ & $U_{R}=20627.160$ & \\
\hline \multirow{2}{*}{1100} & $T_{C}=0.0031$ & $P_{N}=1.0082$ & $U_{C}=1040.630$ & $Y=76.824$ \\
\hline & $T_{R}=0.3351$ & $P_{M}=0.7875$ & $U_{R}=20525.390$ & \\
\hline \multirow{2}{*}{1200} & $T_{C}=0.0034$ & $P_{N}=1.0068$ & $U_{C}=1040.555$ & $Y=76.711$ \\
\hline & $T_{R}=0.3355$ & $P_{M}=0.7862$ & $U_{R}=20429.440$ & \\
\hline \multirow{2}{*}{1300} & $T_{C}=0.0037$ & $P_{N}=1.0057$ & $U_{C}=1040.492$ & $Y=76.617$ \\
\hline & $T_{R}=0.3358$ & $P_{M}=0.7852$ & $U_{R}=20338.760$ & \\
\hline \multirow{2}{*}{1400} & $T_{C}=0.0039$ & $P_{N}=1.0047$ & $U_{C}=1040.438$ & $Y=76.536$ \\
\hline & $T_{R}=0.3361$ & $P_{M}=0.7843$ & $U_{R}=20252.890$ & \\
\hline \multirow{2}{*}{1500} & $T_{C}=0.0041$ & $P_{N}=1.0039$ & $U_{C}=1040.391$ & $Y=76.465$ \\
\hline & $T_{R}=0.3363$ & $P_{M}=0.7835$ & $U_{R}=20171.440$ & \\
\hline \multirow{2}{*}{1600} & $T_{C}=0.0043$ & $P_{N}=1.0031$ & $U_{C}=1040.350$ & $Y=76.404$ \\
\hline & $T_{R}=0.3365$ & $P_{M}=0.7828$ & $U_{R}=20094.070$ & \\
\hline \multirow{2}{*}{1700} & $T_{C}=0.0044$ & $P_{N}=1.0025$ & $U_{C}=1040.314$ & $Y=76.350$ \\
\hline & $T_{R}=0.3367$ & $P_{M}=0.7822$ & $U_{R}=20020.490$ & \\
\hline \multirow{2}{*}{1800} & $T_{C}=0.0046$ & $P_{N}=1.0019$ & $U_{C}=1040.282$ & $Y=76.302$ \\
\hline & $T_{R}=0.3369$ & $P_{M}=0.7816$ & $U_{R}=19950.440$ & \\
\hline \multirow{2}{*}{1900} & $T_{C}=0.0047$ & $P_{N}=1.0013$ & $U_{C}=1040.253$ & $Y=76.259$ \\
\hline & $T_{R}=0.3370$ & $P_{M}=0.7811$ & $U_{R}=19883.700$ & \\
\hline \multirow{2}{*}{2000} & $T_{C}=0.0048$ & $P_{N}=1.0009$ & $U_{C}=1040.227$ & $Y=76.220$ \\
\hline & $T_{R}=0.3372$ & $P_{M}=0.7807$ & $U_{R}=19820.050$ & \\
\hline \multirow{2}{*}{2500} & $T_{C}=0.0053$ & $P_{N}=0.9991$ & $U_{C}=1040.129$ & $Y=76.073$ \\
\hline & $T_{R}=0.3377$ & $P_{M}=0.7790$ & $U_{R}=19542.490$ & \\
\hline \multirow{2}{*}{3000} & $T_{C}=0.0055$ & $P_{N}=0.9979$ & $U_{C}=1040.063$ & $Y=75.976$ \\
\hline & $T_{R}=0.3380$ & $P_{M}=0.7779$ & $U_{R}=19321.160$ & \\
\hline \multirow{2}{*}{3500} & $T_{C}=0.0057$ & $P_{N}=0.9971$ & $U_{C}=1040.017$ & $Y=75.907$ \\
\hline & $T_{R}=0.3382$ & $P_{M}=0.7772$ & $U_{R}=19144.600$ & \\
\hline \multirow{2}{*}{4000} & $T_{C}=0.0059$ & $P_{N}=0.9964$ & $U_{C}=1039.982$ & $Y=75.855$ \\
\hline & $T_{R}=0.3384$ & $P_{M}=0.7766$ & $U_{R}=19004.790$ & \\
\hline \multirow{2}{*}{4500} & $T_{C}=0.0060$ & $P_{N}=0.9959$ & $U_{C}=1039.954$ & $Y=75.814$ \\
\hline & $T_{R}=0.3386$ & $P_{M}=0.7761$ & $U_{R}=18895.820$ & \\
\hline \multirow{2}{*}{5000} & $T_{C}=0.0061$ & $P_{N}=0.9956$ & $U_{C}=1039.933$ & $Y=75.782$ \\
\hline & $T_{R}=0.3387$ & $P_{M}=0.7757$ & $U_{R}=18813.200$ & \\
\hline
\end{tabular}


Finally, we provide graphic reportage of results. Figure 1 shows the reaction functions in tariff rates for both China and ROW in cases incorporating and excluding inside money in $\mathrm{CD}$ preferences. The intersection of these two reaction functions yields the Nash equilibrium tariffs. Figure 1.1 shows the Nash tariff rates for the CD preference case incorporating inside money. Nash tariffs for China and ROW are $T_{1}=0.0027, T_{2}=0.3346$, respectively. Figure 1.2 shows Nash tariffs for the CD case excluding inside money. The Nash tariffs for China and ROW are $T_{1}=0.0016$ and $T_{2}=0.0313$ respectively. Thus, as we emphasize above, tariff games incorporating inside money can yield large differences in Nash equilibrium results. Inside money helps countries who run a trade deficit increase the Nash tariffs, and lower the retaliatory power of countries who run a trade surplus.

We present Nash tariffs and reaction functions of tariffs for CES and CD preferences incorporating inside money in Figure 2. A noteworthy feature of Figure 2 is that Nash tariffs for the 4 CES cases are scattered around the Nash tariffs implied by CD preferences. The gap between China and ROW tariffs is largest when the substitution elasticities for China and ROW are $\sigma_{C}=0.80$ and $\sigma_{R}=0.80$. The gap is narrowed when the substitution elasticities for China and ROW are $\sigma_{C}=1.25$ and $\sigma_{R}=0.80$. The Nash tariffs in CD case are at the center of results for the 4 CES cases. Figure 3 displays the Nash equilibrium tariffs under both CES and CD preferences excluding inside money. Compared to Nash tariffs incorporating inside money, the gap in tariffs between China and ROW is smaller. 
Figure 1. Reaction Functions of Tariff Rates for China and ROW for CD Preferences

1.1 with Inside Money

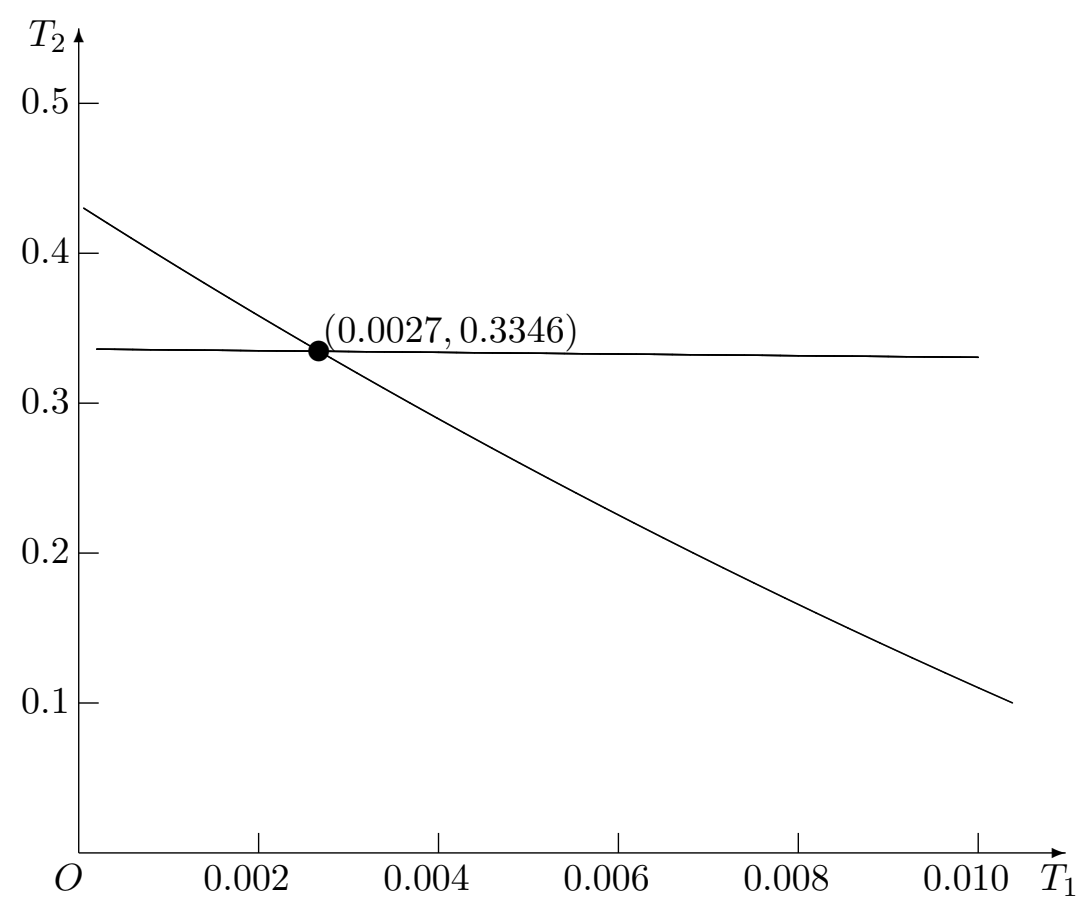

1.2 without Inside Money

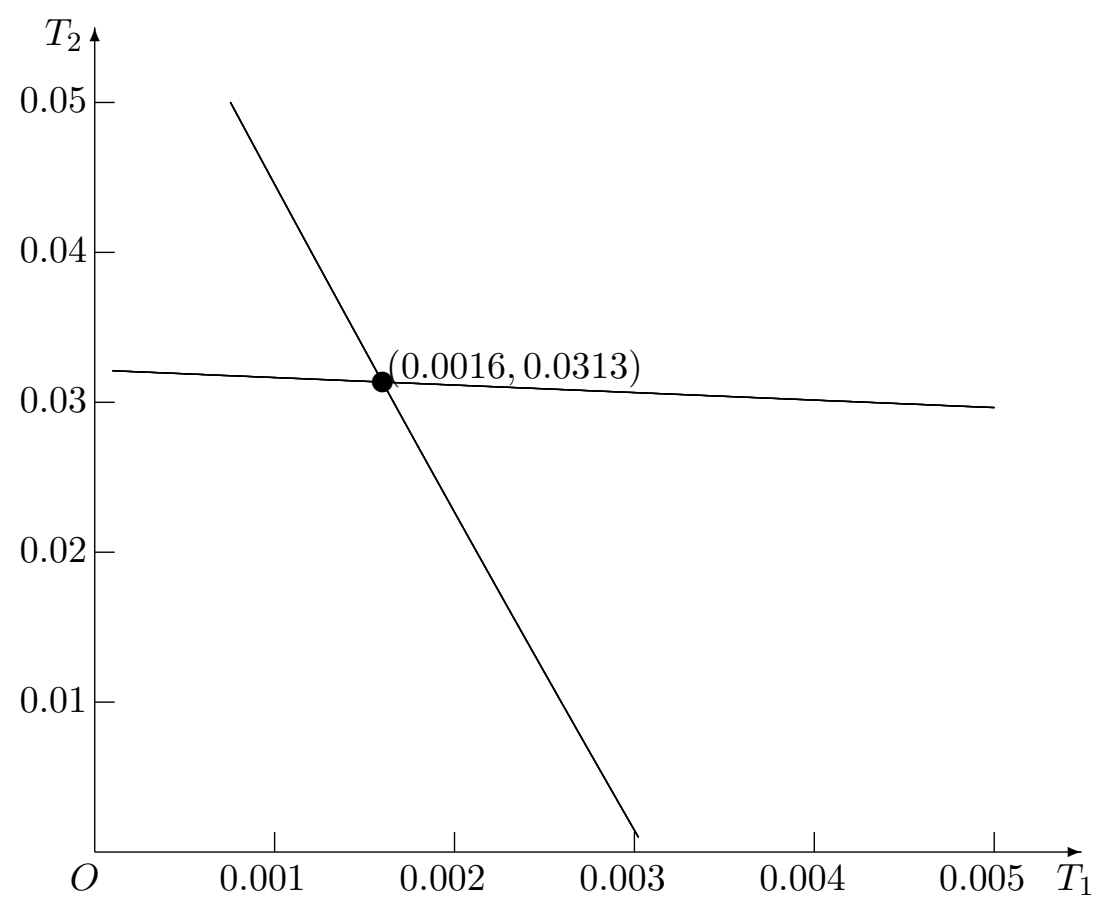


Figure 2. Nash Equilibria and Reaction Functions for China and ROW for CD and CES Preferences Incorporating Inside Money

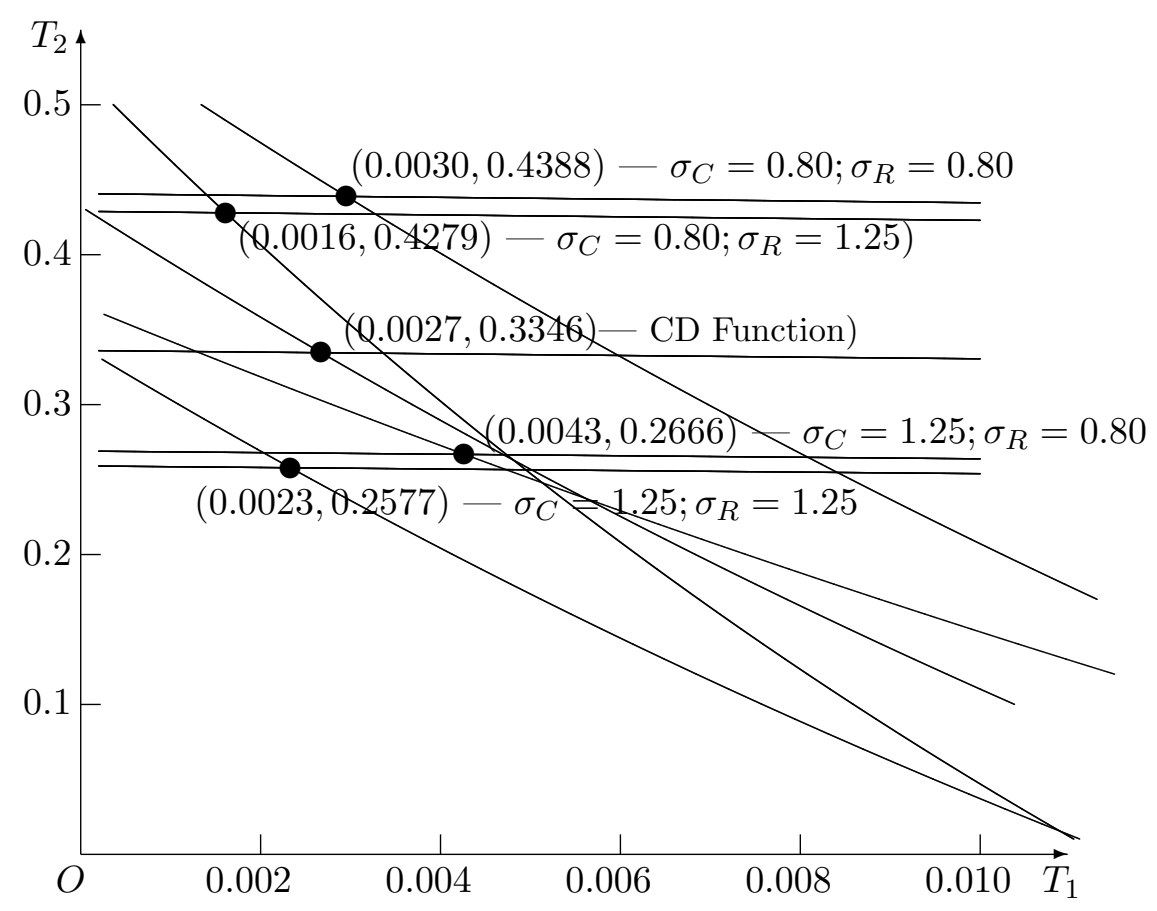

Figure 3. Nash Equilibria and Reaction Functions for China and ROW for CD and CES Preferences Excluding Inside Money

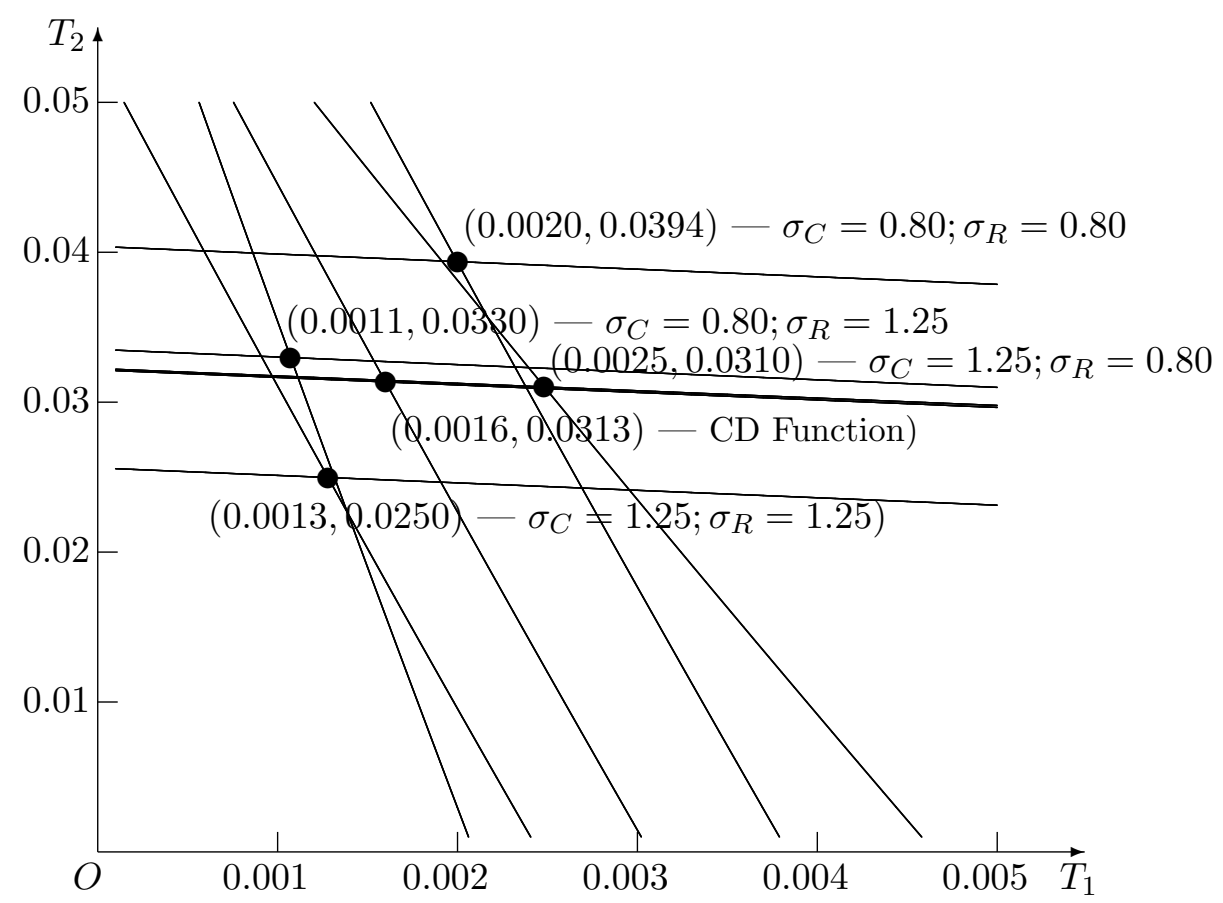




\section{Conclusions and Remarks}

This paper discusses optimal trade policy and Nash outcomes across countries when inside money is present in a monetary-trade model. Countries with trade deficits have enhanced retaliating power compared to a no inside money model, and countries with trade surpluses have lowered retaliating power. We use a conventional goods trade model to numerically explore Nash equilibria, but do so in a structure where, with inside money, trade imbalances are endogenously determined. We present numerical simulation results which show that Nash equilibria for the two cases for similarly calibrated model parameterizations with and without inside money can be quite different. Thus, using structures incorporating or not incorporating endogenous trade imbalances can have a significant impact on model implications for optimal commercial policy. We also report sensitivity analysis for elasticity parameters. We conclude by suggesting that in today's world where large countries such as China and the US run large surpluses and deficits recognizing these in analyses of their commercial policy is important. 


\section{References}

[1] Archibald G. C and R. G. Lipsey (1958), Monetary and Value Theory: A Critique of Lange and Patinkin. Review of Economic Studies 26(1), 1-22.

[2] Abrego, L., R. Riezman and J. Whalley (2003), How Reasonable are Assumptions used in Theoretical Models? Computational Evidence on the Likelihood of Trade Pattern Changes. Canadian Journal of Economics 39, 781-789.

[3] Azariadis, C. (1993), Intertemporal Macroeconomics. Blackwell.

[4] Buiter, W. H. (1981), Time Preference and International Lending and Borrowing in an Overlapping Generations Model. Journal of Political Economy 89, 769-797.

[5] Gorman, W. M. (1958), Tariffs, Retaliation, and the Elasticity of Demand for Imports. The Review of Economic Studies, 25, 133-162.

[6] Hamilton, B., and J. Whalley (1983), Optimal Tariff Calculations in Alternative Trade Models and Some Possible Implications for Current World Trading Arrangements. Journal of International Economics, 15, 323-348.

[7] Johnson, H. G. (1953), Optimum Tariffs and Retaliation. Review of Economic Studies 21, 142-153.

[8] Kuga, K. (1973), Tariff Retaliation and Policy Equilibrium. Journal of International Economics 3, 351-366.

[9] Patinkin, D. (1971), Inside Money, Monopoly Bank profits, and the Real-Balance Effect: Comment. Journal of Money, Credit and Banking 3, 271 - 275.

[10] The United Nations Conference on Trade and Development (UNCTAD), Handbook of Statistics $200 \%$.

http://www.unctad.org/Templates/Page.asp?intItemID=1890\&lang=1.

[11] The World Bank (2007), 2007 World Development Indicators.

http://siteresources.worldbank.org/INTRES/Resources/469232-

1107449512766/WDI_table6_7_tariff_barriers.xls.

[12] The World Bank (2007), Global Purchasing Power Parities and Real Expenditures (2005 International Comparison Program).

http://siteresources.worldbank.org/ICPINT/Resources/icp-final.pdf. 


\section{CESifo Working Paper Series}

for full list see www.cesifo-group.org/wp

(address: Poschingerstr. 5, 81679 Munich, Germany, office@cesifo.de)

2461 Wolfgang Ochel, The Political Economy of Two-tier Reforms of Employment Protection in Europe, November 2008

2462 Peter Egger and Doina Maria Radulescu, The Influence of Labor Taxes on the Migration of Skilled Workers, November 2008

2463 Oliver Falck, Stephan Heblich and Stefan Kipar, The Extension of Clusters: Differencein-Differences Evidence from the Bavarian State-Wide Cluster Policy, November 2008

2464 Lei Yang and Keith E. Maskus, Intellectual Property Rights, Technology Transfer and Exports in Developing Countries, November 2008

2465 Claudia M. Buch, The Great Risk Shift? Income Volatility in an International Perspective, November 2008

2466 Walter H. Fisher and Ben J. Heijdra, Growth and the Ageing Joneses, November 2008

2467 Louis Eeckhoudt, Harris Schlesinger and Ilia Tsetlin, Apportioning of Risks via Stochastic Dominance, November 2008

2468 Elin Halvorsen and Thor O. Thoresen, Parents' Desire to Make Equal Inter Vivos Transfers, November 2008

2469 Anna Montén and Marcel Thum, Ageing Municipalities, Gerontocracy and Fiscal Competition, November 2008

2470 Volker Meier and Matthias Wrede, Reducing the Excess Burden of Subsidizing the Stork: Joint Taxation, Individual Taxation, and Family Splitting, November 2008

2471 Gunther Schnabl and Christina Ziegler, Exchange Rate Regime and Wage Determination in Central and Eastern Europe, November 2008

2472 Kjell Erik Lommerud and Odd Rune Straume, Employment Protection versus Flexicurity: On Technology Adoption in Unionised Firms, November 2008

2473 Lukas Menkhoff, High-Frequency Analysis of Foreign Exchange Interventions: What do we learn?, November 2008

2474 Steven Poelhekke and Frederick van der Ploeg, Growth, Foreign Direct Investment and Urban Concentrations: Unbundling Spatial Lags, November 2008

2475 Helge Berger and Volker Nitsch, Gotcha! A Profile of Smuggling in International Trade, November 2008 
2476 Robert Dur and Joeri Sol, Social Interaction, Co-Worker Altruism, and Incentives, November 2008

2477 Gaëtan Nicodème, Corporate Income Tax and Economic Distortions, November 2008

2478 Martin Jacob, Rainer Niemann and Martin Weiss, The Rich Demystified - A Reply to Bach, Corneo, and Steiner (2008), November 2008

2479 Scott Alan Carson, Demographic, Residential, and Socioeconomic Effects on the Distribution of $19^{\text {th }}$ Century African-American Stature, November 2008

2480 Burkhard Heer and Andreas Irmen, Population, Pensions, and Endogenous Economic Growth, November 2008

2481 Thomas Aronsson and Erkki Koskela, Optimal Redistributive Taxation and Provision of Public Input Goods in an Economy with Outsourcing and Unemployment, December 2008

2482 Stanley L. Winer, George Tridimas and Walter Hettich, Social Welfare and Coercion in Public Finance, December 2008

2483 Bruno S. Frey and Benno Torgler, Politicians: Be Killed or Survive, December 2008

2484 Thiess Buettner, Nadine Riedel and Marco Runkel, Strategic Consolidation under Formula Apportionment, December 2008

2485 Irani Arraiz, David M. Drukker, Harry H. Kelejian and Ingmar R. Prucha, A Spatial Cliff-Ord-type Model with Heteroskedastic Innovations: Small and Large Sample Results, December 2008

2486 Oliver Falck, Michael Fritsch and Stephan Heblich, The Apple doesn't Fall far from the Tree: Location of Start-Ups Relative to Incumbents, December 2008

2487 Cary Deck and Harris Schlesinger, Exploring Higher-Order Risk Effects, December 2008

2488 Michael Kaganovich and Volker Meier, Social Security Systems, Human Capital, and Growth in a Small Open Economy, December 2008

2489 Mikael Elinder, Henrik Jordahl and Panu Poutvaara, Selfish and Prospective: Theory and Evidence of Pocketbook Voting, December 2008

2490 Maarten Bosker and Harry Garretsen, Economic Geography and Economic Development in Sub-Saharan Africa, December 2008

2491 Urs Fischbacher and Simon Gächter, Social Preferences, Beliefs, and the Dynamics of Free Riding in Public Good Experiments, December 2008

2492 Michael Hoel, Bush Meets Hotelling: Effects of Improved Renewable Energy Technology on Greenhouse Gas Emissions, December 2008 
2493 Christian Bruns and Oliver Himmler, It's the Media, Stupid - How Media Activity Shapes Public Spending, December 2008

2494 Andreas Knabe and Ronnie Schöb, Minimum Wages and their Alternatives: A Critical Assessment, December 2008

2495 Sascha O. Becker, Peter H. Egger, Maximilian von Ehrlich and Robert Fenge, Going NUTS: The Effect of EU Structural Funds on Regional Performance, December 2008

2496 Robert Dur, Gift Exchange in the Workplace: Money or Attention?, December 2008

2497 Scott Alan Carson, Nineteenth Century Black and White US Statures: The Primary Sources of Vitamin D and their Relationship with Height, December 2008

2498 Thomas Crossley and Mario Jametti, Pension Benefit Insurance and Pension Plan Portfolio Choice, December 2008

2499 Sebastian Hauptmeier, Ferdinand Mittermaier and Johannes Rincke Fiscal Competition over Taxes and Public Inputs: Theory and Evidence, December 2008

2500 Dirk Niepelt, Debt Maturity without Commitment, December 2008

2501 Andrew Clark, Andreas Knabe and Steffen Rätzel, Boon or Bane? Others' Unemployment, Well-being and Job Insecurity, December 2008

2502 Lukas Menkhoff, Rafael R. Rebitzky and Michael Schröder, Heterogeneity in Exchange Rate Expectations: Evidence on the Chartist-Fundamentalist Approach, December 2008

2503 Salvador Barrios, Harry Huizinga, Luc Laeven and Gaëtan Nicodème, International Taxation and Multinational Firm Location Decisions, December 2008

2504 Andreas Irmen, Cross-Country Income Differences and Technology Diffusion in a Competitive World, December 2008

2505 Wenan Fei, Claude Fluet and Harris Schlesinger, Uncertain Bequest Needs and LongTerm Insurance Contracts, December 2008

2506 Wido Geis, Silke Uebelmesser and Martin Werding, How do Migrants Choose their Destination Country? An Analysis of Institutional Determinants, December 2008

2507 Hiroyuki Kasahara and Katsumi Shimotsu, Sequential Estimation of Structural Models with a Fixed Point Constraint, December 2008

2508 Barbara Hofmann, Work Incentives? Ex Post Effects of Unemployment Insurance Sanctions - Evidence from West Germany, December 2008

2509 Louis Hotte and Stanley L. Winer, The Demands for Environmental Regulation and for Trade in the Presence of Private Mitigation, December 2008 
2510 Konstantinos Angelopoulos, Jim Malley and Apostolis Philippopoulos, Welfare Implications of Public Education Spending Rules, December 2008

2511 Robert Orlowski and Regina T. Riphahn, The East German Wage Structure after Transition, December 2008

2512 Michel Beine, Frédéric Docquier and Maurice Schiff, International Migration, Transfers of Norms and Home Country Fertility, December 2008

2513 Dirk Schindler and Benjamin Weigert, Educational and Wage Risk: Social Insurance vs. Quality of Education, December 2008

2514 Bernd Hayo and Stefan Voigt, The Relevance of Judicial Procedure for Economic Growth, December 2008

2515 Bruno S. Frey and Susanne Neckermann, Awards in Economics - Towards a New Field of Inquiry, January 2009

2516 Gregory Gilpin and Michael Kaganovich, The Quantity and Quality of Teachers: A Dynamic Trade-off, January 2009

2517 Sascha O. Becker, Peter H. Egger and Valeria Merlo, How Low Business Tax Rates Attract Multinational Headquarters: Municipality-Level Evidence from Germany, January 2009

2518 Geir H. Bjønnes, Steinar Holden, Dagfinn Rime and Haakon O.Aa. Solheim, ,Large’ vs. ,Small' Players: A Closer Look at the Dynamics of Speculative Attacks, January 2009

2519 Jesus Crespo Cuaresma, Gernot Doppelhofer and Martin Feldkircher, The Determinants of Economic Growth in European Regions, January 2009

2520 Salvador Valdés-Prieto, The 2008 Chilean Reform to First-Pillar Pensions, January 2009

2521 Geir B. Asheim and Tapan Mitra, Sustainability and Discounted Utilitarianism in Models of Economic Growth, January 2009

2522 Etienne Farvaque and Gaël Lagadec, Electoral Control when Policies are for Sale, January 2009

2523 Nicholas Barr and Peter Diamond, Reforming Pensions, January 2009

2524 Eric A. Hanushek and Ludger Woessmann, Do Better Schools Lead to More Growth? Cognitive Skills, Economic Outcomes, and Causation, January 2009

2525 Richard Arnott and Eren Inci, The Stability of Downtown Parking and Traffic Congestion, January 2009

2526 John Whalley, Jun Yu and Shunming Zhang, Trade Retaliation in a Monetary-Trade Model, January 2009 